\title{
Air temperature changes in the Arctic in the period 1951-2015 in the light of observational and reanalysis data
}

\author{
Rajmund Przybylak ${ }^{1} \cdot$ Przemysław Wyszyński $^{1}$ iD
}

Received: 23 January 2019 / Accepted: 8 July 2019 / Published online: 31 July 2019

(C) The Author(s) 2019

\begin{abstract}
Recent air temperature changes in the high Arctic (HA) have been investigated based on mean seasonal and annual data calculated for the period 1951-2015 and for two sub-periods 1976-2015 and 1996-2015. Two kinds of air temperature data (observational and reanalysis) have been used in the research. The observational data were compared with data taken from six reanalysis products (20CRv2c, CERA-20C, ERA-Int, MERRA-2, NCEP-CFSRR, JRA-55). The scale of the HA warming for the period 1996-2015 relative to the reference period 1951-1990 reached $1.6^{\circ} \mathrm{C}$ for annual mean and was greatest in autumn $\left(1.9^{\circ} \mathrm{C}\right)$ and in winter $\left(1.7^{\circ} \mathrm{C}\right)$, while it was smallest in summer $\left(0.9^{\circ} \mathrm{C}\right)$. Evidently, the greatest warming was observed in the Atlantic and Siberian climatic regions, while in the rest of the HA, the rate of warming was usually weaker than trends calculated for the period 1976-2015. Air temperature tendencies in all study periods 1951-2015, 1976-2015 and 1996-2015 showed a predominance of positive trends that were statistically significant at the level of 0.05 . In the two latter periods, the rate of warming was on average 2-3 times faster than for the entire study period. In the HA, there has not been a slowdown in the rate of warming ("hiatus") in the last two decades (in contrast to that which was noted for the Northern Hemisphere). Our results reveal that, in most cases, the closest fit to observations was obtained for two reanalysis products (the ERA-Interim and JRA-55, since 1979) and the six reanalysis average. Two new polar amplification (PA) metrics based on scaled and standardised values of surface air temperature (SAT) reveal the non-existence of this phenomenon in the period 1951-2015. One of the metrics shows very small PA in the periods 1976-2015 and 1996-2015.
\end{abstract}

\section{Introduction}

A myriad of papers published recently document large, and sometimes even dramatic, environmental changes in the Arctic (see, e.g. ACIA 2004; IPCC 2013) as a consequence of its recent warming, which Overland et al. (2016) describe as "unequivocal, substantial and ongoing". The most spectacular and important changes in terms of their consequences for both the Arctic and global climate are those observed in the cryosphere, and in particular in the extent and thickness of sea ice. Suffice to say that, since 1979, the 10 lowest minimum Arctic sea ice extents occurred in the period 2007-2017

Electronic supplementary material The online version of this article (https://doi.org/10.1007/s00704-019-02952-3) contains supplementary material, which is available to authorized users.

Przemysław Wyszyński

przemyslaw.wyszynski@umk.pl

1 Department of Meteorology and Climatology, Nicolaus Copernicus University, 87-100 Toruń, Poland (including the year 2012, when the lowest value - of only 3.41 million $\mathrm{km}^{2}$ - was noted, see: http://nsidc.org/ arcticseaicenews/2012/09/arctic-sea-ice-extent-settles-atrecord-seasonal-minimum/). Land ice, including the Greenland ice sheet, is also undergoing visible changes, seen, among others, in great losses in ice mass and retreats of termini of glaciers (see, e.g. Dowdeswell et al. 1997; Harig and Simons 2012).

Studies that would improve our knowledge of the influence of Arctic warming in terms of changes observed both in its environment and in climate conditions at lower latitudes urgently need good quality information on changes in the principal climate variable, i.e. 2-m air temperature (hereinafter SAT), in recent decades. To obtain such quality of information, the collected instrumental data should fulfil the following criteria: (a) the number of data series for each year, season and month of the study period should be identical, which unfortunately is not the rule in many works (see, e.g. Polyakov et al. 2003); (b) all data should be quality controlled and homogeneous; (c) if possible, should be taken directly from meteorological institutes (or other institutions) responsible for 
collecting data for the Arctic area; and (d) the network of stations should be evenly distributed. Cowtan and Way (2014) found that gridded air temperature datasets (Hadley Centre and the Climatic Research Unit (HadCRUT, Morice et al. 2012), NASA's Goddard Institute for Space Studies Surface Temperature Analysis (GISTEMP) product (Hansen et al. 2010), the National Climatic Data Center (NCDC) product (Smith et al. 2008)), all of which used station data (Global Historical Climatology Network, GHCN) processed by automated homogenisation algorithms, may result in recent warming in the Eurasian Arctic being underestimated due to systematic downward adjustments to the raw data. Rapaic et al. (2015) analysed 16 gridded databases (including 8 reanalysis products) for the Canadian Arctic and found important differences between them in terms of spatial distributions, temporal variability, yearly cycle, etc. The greatest differences were found for mountain and coastal regions, as well as for the Canadian Arctic Archipelago. They suggest that care should be taken in using these gridded products in local- or regionalscale applications. Additionally, Way et al. (2017) recently showed that data taken from a new land-only product developed within the Berkeley Earth Surface Temperatures (BEST) project (Rohde et al. 2013), and which were not used by Rapaić et al. (2015), reveal an underestimation of recent warming in northern Canada when compared against data taken from the Adjusted and Homogenized Canadian Climate Dataset (ADHCCD) developed by Environment Canada. They also stated that automated station adjustment algorithms reduce air temperature changes in this region and are sensitive to declines in the long-term observing network. Their next very important conclusion is that for northern Canada, as well for other Arctic regions with a sparse station network, "there is still a need for manual homogenization procedures to compensate for station relocations and variable time of observations ...". This short review leads to the conclusion that the best solution in the study of SAT trends, in particular for periods starting before 1979 (the onset of the satellite era) in almost the entire Arctic (excluding the inner part of the Arctic Ocean), where weather-station coverage is limited (Przybylak 2000; Cowtan and Way 2014), is still to use good quality homogenised data series from those stations.

For many years, Przybylak (1996, 2000, 2002, 2007, 2016) has consequently used such data to study SAT changes in the high Arctic (hereinafter HA) as delimited by climatic criteria proposed in the Atlas Arktiki (Treshnikov 1985, see also Fig. 1). This has made it possible to reliably estimate the SAT changes in a large part of the HA (excluding Interior Arctic and Greenland climatic regions) for the following full period and incremental overlapping periods 1951-1990, 1951-1995, 1951-2000, 1951-2005 and 1951-2010.

The large warming of the HA, which has remained at a constantly high level for more than two decades (since mid1990s), must be regularly monitored and that is why we decided here to update the SAT history until 2015 using almost the same set of stations which Przybylak used in his mentioned papers. In recent years, reanalyses have been a very popular source of data for climate studies, and therefore, in the present paper, we also used this kind of data taken from the six newest different reanalysis products (see next section). Serreze and Barry (2014) claim that, due to discrepancies in reanalyses, it is necessary to take under consideration the averages from multiple reanalysed data to properly analyse the mean state of the Arctic climate system.

The main aim of the present paper is to identify directions and scales of spatio-temporal SAT changes in the HA in the long-term (1951-2015) and in the short-term (1996-2015) that have resulted from the updating of instrumental series up till 2015. The main focus is, however, on the latter period, which we have described as the "recent rapid Arctic warming" period (hereinafter RRAW). In addition, the important aim of this paper is also to indicate which reanalysis products are most reliable and accord most closely with our series of instrumental observations.

A list of all abbreviations used in this paper is provided in Appendix S1. Some of the most important for the understanding of the paper are also introduced in the text.

\section{Area, data and methods}

The monthly means of SAT $\left({ }^{\circ} \mathrm{C}\right)$ for the period $1951-2015$ from 37 meteorological stations located in HA (Fig. 1) were taken for analysis. Seven auxiliary sub-Arctic sites were used as a support in the spatial analysis. A comprehensive list of the data sources, quality control and homogeneity details can be found in previous works of Przybylak (1996, 2000, 2002). The set of these stations fulfils all four of the abovementioned criteria necessary for reliable estimates of SAT changes in the HA. SAT $\left({ }^{\circ} \mathrm{C}\right)$ anomalies with respect to 1981-2010 climate normal and 1951-1990 long-term mean have been calculated. The recent WMO climate normal (1981-2010) has been used in order to compare observational data for anomalies against reanalyses, and the earlier base period (1951-1990) has been used to compare observational data with the results provided in previous studies: Przybylak (1996, 2000, 2002, 2007, 2016). In the next step, seasonal (DJF, MAM, JJA, SON) and annual SAT anomalies were averaged for each site, as well as for each climatic region and the entire HA.

Besides observational datasets, six global reanalysis products were also used as an estimation of Arctic SAT variability in the period 1951-2015, i.e. 20CRv2c (Compo et al. 2011), CERA-20C (Laloyaux et al. 2016), ERA-Int (Dee et al. 2011), JRA-55 (Kobayashi et al. 2015), MERRA-2 (Gelaro et al. 2017) and NCEP-CFSR (Saha et al. 2010). We have not used all currently existing reanalyses, but only a few newer ones 


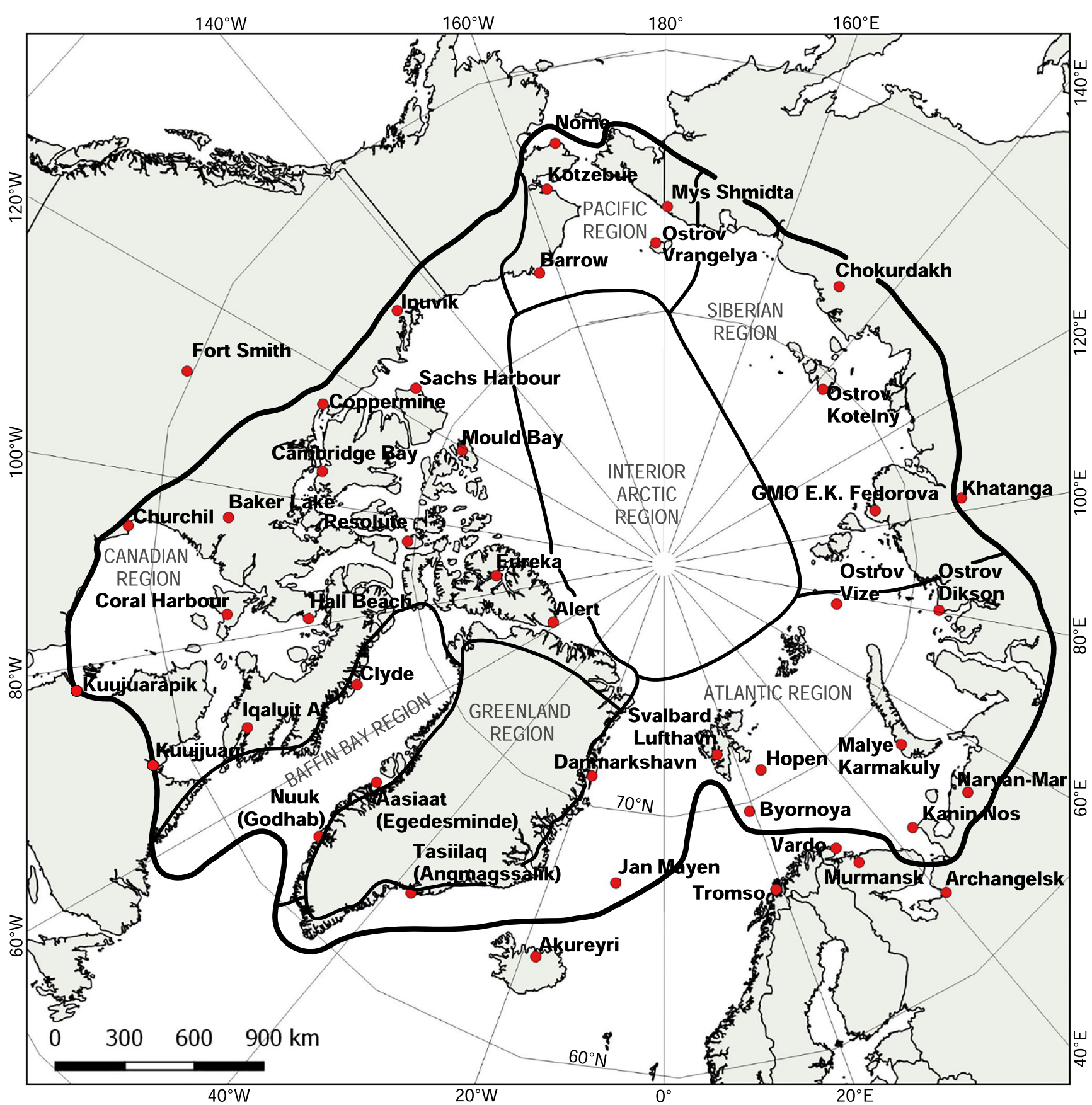

Fig. 1 Location of meteorological stations (dots) used in the study. Key: Thick line indicates border of high Arctic (HA) after Treshnikov (1985); thin lines indicate borders of climatic regions

(Fujiwara et al. 2017). They were then compared with observations. Of all the reanalyses used in the paper, only ERA-Int and JRA-55 assimilate SAT from land (Simmons et al. 2017; Zhou et al. 2018). It must be noted that not all of them fully cover the analysed period. Table S1 presents the basic characteristics of the reanalyses used in our study.

More details about assimilated data, methods of data assimilation, forecast model specifications, selected physical parametrisations, boundary conditions, etc. may be found in many published and on-line comprehensive reanalyses comparison tables, e.g. Reanalyses.org (https://reanalyses. org/atmosphere/comparison-table), Dee et al. (2016, https:// climatedataguide.ucar.edu/climate-data/atmosphericreanalysis-overview-comparison-tables) and Fujiwara et al. (2017).

In order to compare reanalyses to observations, the nearest gridpoint to the coordinates of each meteorological station was chosen. Choosing the nearest gridpoint is a method commonly used in a reanalysis evaluation procedure (e.g. Klaus et al. 2018). However, Cullather et al. (2016) indicate that 
"there is a 'representativeness' error associated with the point measurements, since the gridded analysis is intended to estimate the average state of a grid volume". The same calculations as for observations were performed for the reanalysed values.

Seasonal and annual linear SAT trends were calculated for the periods 1951-2015, 1976-2015 and 1996-2015, as well as fit statistics, i.e. correlation coefficients $(r)$ and root mean square errors (RMSE, ${ }^{\circ} \mathrm{C}$ ) between observational and reanalysed values on the basis of the least-squares regression method (Wilks 2011). For spatial analysis, the ordinary kriging interpolation technique has been applied as it provides only small errors in the distribution of SAT anomalies in the Arctic (Dodd et al. 2015).

Furthermore, our results have been compared with three commonly used, recently gridded datasets, i.e. CRUTEM4 (Jones et al. 2012), HadCRUT4 (Morice et al. 2012) and BEST (Rohde et al. 2013) for the Arctic (defined as the 60$90^{\circ} \mathrm{N}$ latitudinal belt), as well as for the whole Northern Hemisphere (Morice et al. 2012; Rohde et al. 2013). CRUTEM4 contains land air temperature anomalies on a $5 \times 5^{\circ}$ grid, while HadCRUT4 are the combined land temperature anomalies (CRUTEM4) and marine temperature anomalies (SST anomalies from HadSST3, Kennedy et al. 2011) on a $5 \times 5^{\circ}$ grid. In the case of the BEST dataset, its primary product - an analysis of summary air temperatures over land - has been utilised in this paper. Furthermore, we utilised BEST land + ocean, which combines the Berkeley Earth landsurface temperature field with a re-interpolated version of the HadSST3 ocean temperature field. We used the version where temperature anomalies in the presence of sea ice are extrapolated from land-surface air temperature anomalies; for more details, see Rohde et al. (2013). Spatial resolution of BEST product is a $1 \times 1^{\circ}$ latitude-longitude grid.

Besides the entire study period (1951-2015), we decided to also distinguish two sub-periods (1976-2015 and 1996-2015) for analysis of different aspects of SAT changes (anomalies, trends, etc.). The former period represents the second phase of global warming (the first [1920-1940] is known as the early twenty century warming [ETCW]) and is referred to here as contemporary global warming [hereinafter $\mathrm{CGW}$ ] and the latter represents most adequately the RRAW period. Both of these starting years are very well known in the literature (see Przybylak 2000, 2007; IPCC 2013; http://cdiac.ess-dive.lbl. gov/trends/temp/jonescru/jones.html). The regime shift detection algorithm (Rodionov 2004) utilised on our Arctic SAT series confirms the occurrence of a rapid change in mean annual SATs in 1995 (by $1.33{ }^{\circ} \mathrm{C}$ ), as well as in spring and autumn (see Fig. 2). In addition, the next shift was found also for the year 2005 , but was slightly smaller $\left(1.28^{\circ} \mathrm{C}\right)$. The latter shift was also noted for seasonal values, except spring.

From Fig. 1, it is clearly seen that long-term series of instrumental SAT are not available for two climatic regions: the interior Arctic region and the Greenland region. Therefore, these areas of the HA are generally excluded from the analysis presented in the paper. Only probable locations of isolines describing SAT anomalies and trends were drawn using dashed lines for the mentioned climatic regions. This decision was taken because Martin et al. (1997) found that air temperature changes in 1961-1990 obtained from drifting stations were "consistent with the land station observations, and suggest, now that the NP [North Polar drifting stations - authors' suppl.] temperatures are no longer being acquired, that the land stations might be used as a proxy for these observations". A similar conclusion is also presented by Rigor et al. (2000) based on analysis of SAT derived from a gridded dataset called POLES (Polar Exchange at the Sea Surface) for the period 1979-1997. These data were estimated from the optimal interpolation of inputs from different buoys (International Arctic Buoy Programme, IABP), manned Soviet North Pole drifting ice stations, coastal land weather stations and ship reports. For the Greenland region, we have also drawn a probable run of isolines (dashed lines) using available SAT characteristics for coastal stations. We decided to do this because trends calculated for the Greenland interior for the periods 1951-2015, 1976-2015 and 1996-2015 using our method were similar to areally averaged seasonal and annual trends for the whole Greenland region (meant as the latitudinal/longitudinal range from 59.78 to $83.63^{\circ} \mathrm{N}$ and from 73.26 to $11.31^{\circ} \mathrm{W}$ ) received from 88 monthly temperature series (including coastal and interior ice cap automatic weather stations) taken from the BEST dataset (not shown).

Polar (Arctic) amplification (PA), described recently in detail by Davy et al. (2018), was calculated in the paper using seven methods (metrics); among them, we propose two new ones based on scaled mean SAT anomalies (PA6) and trends of standardised SAT anomalies (PA7) (see Table 1 for details), because we agree with the suggestion of Davy et al. (2018) saying that the magnitude of the variability in comparable areas (here the Arctic and the Northern Hemisphere) should also be taken into account.

Standardisation of SAT for HA and NH was made according to the following formula (Wilks 2011):

\section{$\mathrm{SAT}_{\mathrm{SD}}=\left(\mathrm{SAT}-\mathrm{SAT}_{\mathrm{MEAN}}\right) / \mathrm{SD}$}

Where $\mathrm{SAT}_{\mathrm{SD}}$ is the standardised monthly mean anomaly, SAT is the non-standardised variable, SAT $_{\text {MEAN }}$ is the arithmetic mean and SD is the standard deviation from the time series. Calculated linear trends for $\mathrm{SAT}_{\mathrm{SD}}$ values allowed us to construct the PA7 metric. Note that PA7 is based on standardised SATs, and PA6 is scaled to the magnitude of the variability where non-standardised mean SAT anomaly is simply divided by the SD of the time series (Table 1). Finally, we calculated the ratio between $\mathrm{HA}$ and $\mathrm{NH}$. 

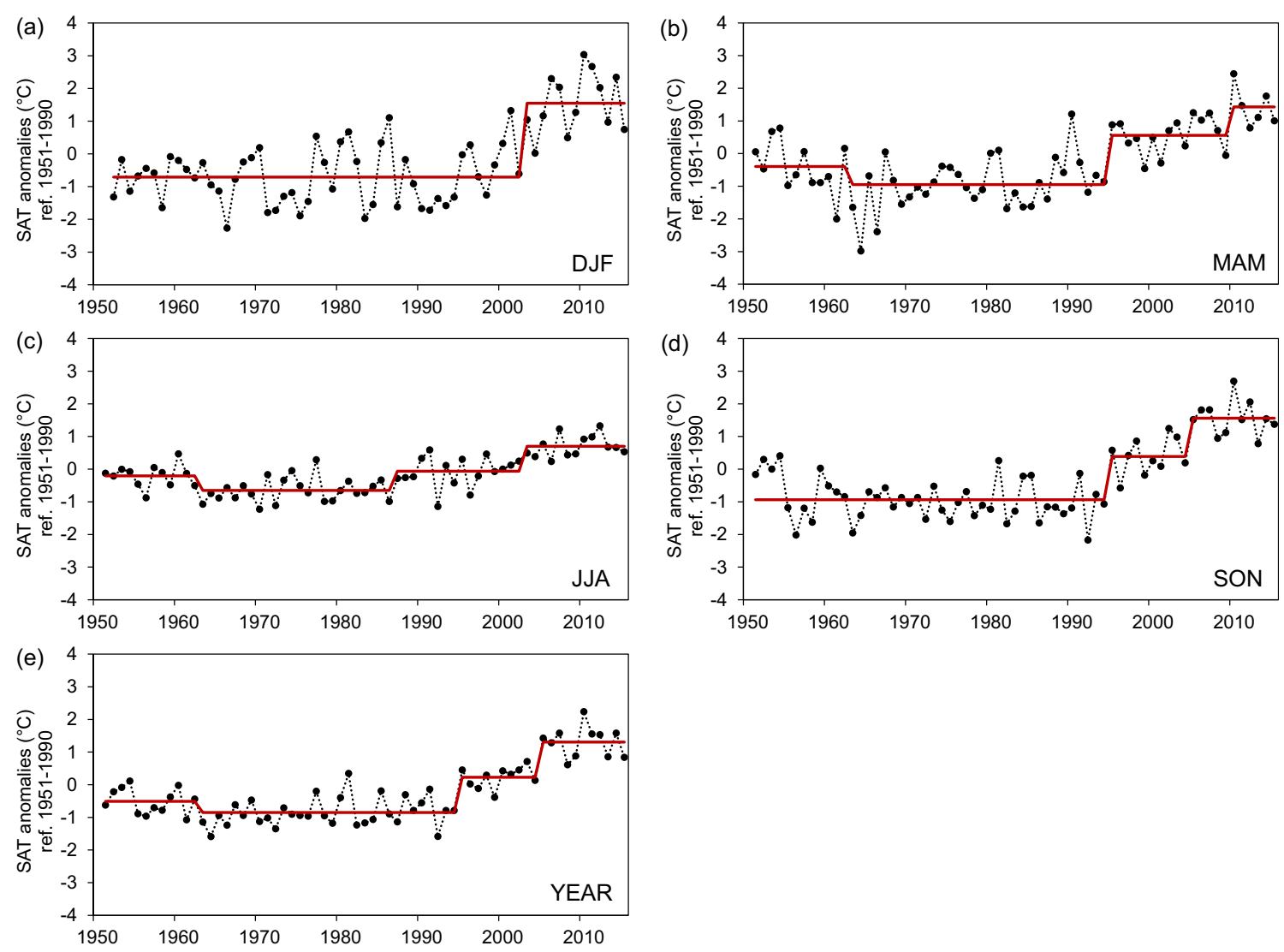

Fig. 2 Regime shifts of the HA temperature series detected by the Rodionov test for a-d seasonal and $\mathbf{e}$ annual means in the period 19512015 with significance level $p=0.05$ determined by Student's $t$ test. (Cut-

In all metrics (except PA2, which uses differences between sets of SAT data instead of their ratios), values greater than 1.0 denote the occurrence of PA, while lower than 1.0 mean a greater increase of NH SAT than HA SAT. We propose to call this phenomenon "non-polar amplification" (hereinafter NPA).

\section{Results and discussion}

\subsection{Instrumental observations}

The structure of the presented analysis of recent changes in SAT in the HA until 2015 is similar to those used in previous analyses of that kind presented by Przybylak (1996, 2000, 2002, 2007, 2016). Summarising those results briefly, it must underlined that in the HA, after 1975 (start of NH warming, including sub-Arctic), warming was not seen until the mid1990s. As a result, trends in SAT from 1951 until 1995 were still mainly decreasing (Przybylak 2000, see also Table S2). The abrupt rise in SAT in the mid-1990s, first documented by Przybylak (2007), changed this pattern significantly. For the periods 1951-2000, 1951-2005 and 1951-2010, trends in SAT were mainly increasing in all seasons and climatic

off length was 10). Shifts were detected after data prewhitening procedure by the IP4 (inverse proportionality with 4 corrections) method (see Rodionov 2006), but original data are plotted

regions, except the Baffin Bay region (hereinafter BAFR) during the first two mentioned periods (Table S2).

For the purposes of the present paper, we have updated all SAT series until 2015 to check if strong warming is still continuing in the HA and, if so, how this fact has influenced the observed magnitude and spatial distribution of trends. As was said earlier, the great and dramatic warming in the HA began in the mid-1990s, and therefore, to quantitatively estimate the scale of this warming, we decided to calculate SAT anomalies from 1996 to 2015 in reference to 1951-1990, which was also used as the reference period in all previous works (Przybylak $2000,2002,2007,2016)$ and is thus very convenient for comparison purposes (Table 2).

Areally averaged SAT in HA in the RRAW period 19962015 was as much as $1.55^{\circ} \mathrm{C}$ warmer than in the reference period. The greatest warming occurred in autumn (by $1.95^{\circ} \mathrm{C}$ ) and winter (by $1.70^{\circ} \mathrm{C}$ ), while the smallest was in summer (by $0.90^{\circ} \mathrm{C}$ ) (Table 2). Seasonal and annual anomalies calculated for this period were about 2 times greater than those calculated for the period of CGW, i.e. 1976-2015. The recent HA warming is of the same magnitude as the warming observed over lands based on the HadCRUT4 gridded product in the latitude band $60-90^{\circ} \mathrm{N}$ (Arctic 3), while it is markedly warmer (by almost $0.6{ }^{\circ} \mathrm{C}$ for the annual values) than the area that 
also encompasses the oceans (Arctic 2, see Table 2). Ocean data included in the BEST dataset slightly lowered SAT (compare Arctic 4 and Arctic 5), but both these versions of data revealed a slightly smaller warming (by $0.2^{\circ} \mathrm{C}$ ) in the 1995 2015 period than that noted in HA (Table 2).

The annual values for HA warming in the RRAW period were as much as 2.5 times greater than the warming of the Northern Hemisphere (NH 1) and were slightly greater than in the CGW period (see Table 2). In the cold half-year, the ratio even reached 3:1 in the former period, while in the latter, it ranged between 2.4 and 2.8 (to 1 ). This effect is usually called polar (or Arctic) amplification (Serreze and Francis 2006; Cowtan and Way 2014; Davy et al. 2018). Besides this method used to calculate PA (PA1 in Table 1), we also used six others (PA2-PA7), including two new metrics (PA6 and PA7) proposed by us in this paper, which were calculated based on scaled and standardised values of HA and NH 1 SATs. All the old metrics (PA1-PA5) show a clear increase in PA with time. In the RRAW period, their values range between 2 and 4 in terms of PA1 and PA3-PA5 metrics (see Table 1). These results are close to that presented by Davy et al. (2018) - see their Figure 2. A clearly greater PA is observed in winter and autumn compared to summer and spring (Table 1).

Davy et al. (2018) calculated PA using four metrics (of which, we also use three: PA2, PA4, PA5 in our Table 1) and eight different datasets: two observational and six reanalysis. They conclude that all metrics used by them showed increasing values of PA from around 1990 to the present. For this reason, here, we do not present results for the six reanalysis products used by us, because exactly the same set of reanalyses was used by Davy et al. (2018).

As is well seen from the analysis of Table 1, and from a review of the literature, all metrics calculated based on nonstandardised values confirm the existence of large PA. On the other hand, metrics based on scaled and standardised values (PA6 and PA7 in Table 1) most often reveal a lack of PA and even the existence of N-PA. In light of the PA6 metric, in all three study periods, N-PA dominates, while in the PA7 metric, this is mainly seen in the period 1951-2015 (Table 1). In two more recent periods (1976-2015 and 1996-2015), a very slight domination of PA is observable. Standardised SAT anomalies of HA and NH 1 run very close to each other in the period 1951-2015 (Fig. 3), and this is in agreement with the calculation of PA using the new metrics, and PA6 and PA7 in particular.

The greatest warming in the RRAW period (by $1.65^{\circ} \mathrm{C}$ ) was noted in the Atlantic region (hereinafter ATLR), with its maximum in winter (by $2.16^{\circ} \mathrm{C}$ ) and minimum in summer (by $0.81{ }^{\circ} \mathrm{C}$ ) (Table 2). An identical magnitude of warming in terms of annual means was also noted in the Canadian region (hereinafter CANR). However, here, a greater warming than in the ATLR was observed in summer and autumn, and a smaller one in winter and spring. Of all climatic regions, the 
Table 2 Mean seasonal and annual SAT anomalies $\left({ }^{\circ} \mathrm{C}\right)$ in the Arctic and its climatic regions from the periods 1976-2015 and 1996-2015 relative to $1951-1990$ mean

\begin{tabular}{|c|c|c|c|c|c|c|c|c|c|c|}
\hline \multirow[t]{2}{*}{ Area } & \multicolumn{5}{|c|}{$1976-2015$} & \multicolumn{5}{|c|}{ 1996-2015 } \\
\hline & DJF & MAM & JJA & SON & YEAR & DJF & MAM & JJA & SON & YEAR \\
\hline ATLR & 1.09 & 1.15 & 0.42 & 0.86 & 0.88 & 2.16 & 1.80 & 0.81 & 1.74 & 1.65 \\
\hline SIBR & 0.69 & 1.03 & 0.37 & 1.19 & 0.83 & 1.18 & 1.87 & 0.71 & 2.35 & 1.54 \\
\hline PACR & 1.09 & 1.05 & 0.68 & 1.18 & 1.03 & 1.44 & 1.70 & 0.93 & 2.25 & 1.60 \\
\hline CANR & 1.03 & 0.79 & 0.59 & 1.14 & 0.91 & 1.85 & 1.39 & 1.03 & 2.22 & 1.65 \\
\hline BAFR & 0.46 & 0.25 & 0.39 & 0.48 & 0.41 & 1.84 & 1.27 & 1.04 & 1.17 & 1.33 \\
\hline Arctic 1 (HA) & 0.87 & 0.85 & 0.49 & 0.97 & 0.81 & 1.70 & 1.61 & 0.90 & 1.95 & 1.55 \\
\hline $\begin{array}{l}\text { Arctic } 2 \text { (land + } \\
\quad \text { ocean) }\end{array}$ & 0.74 & 0.80 & 0.46 & 0.55 & 0.62 & 1.34 & 1.14 & 0.83 & 1.10 & 0.96 \\
\hline Arctic 3 (land only) & 0.92 & 1.03 & 0.43 & 0.97 & 0.84 & 1.66 & 1.68 & 0.79 & 1.89 & 1.52 \\
\hline $\begin{array}{l}\text { Arctic } 4 \text { (land + } \\
\quad \text { ocean) }\end{array}$ & 0.88 & 0.88 & 0.36 & 0.81 & 0.74 & 1.49 & 1.47 & 0.68 & 1.62 & 1.32 \\
\hline Arctic 5 (land only) & 0.89 & 0.89 & 0.40 & 0.80 & 0.75 & 1.44 & 1.45 & 0.74 & 1.51 & 1.30 \\
\hline NH 1 (land + ocean) & 0.36 & 0.38 & 0.33 & 0.35 & 0.36 & 0.57 & 0.62 & 0.59 & 0.63 & 0.61 \\
\hline NH 2 (land + ocean) & 0.39 & 0.41 & 0.32 & 0.38 & 0.38 & 0.65 & 0.67 & 0.57 & 0.70 & 0.65 \\
\hline
\end{tabular}

Key: Arctic 1 -areally averaged temperature based on data from 37 Arctic stations, Arctic 2 - areally averaged temperature for 60-90 $\mathrm{N}$ latitude band (HadCRUT4, land + ocean, after Morice et al. 2012, updated), Arctic 3areally averaged temperature for $60-90^{\circ} \mathrm{N}$ latitude band (CRUTEM4, land only, after Jones et al. 2012, updated), Arctic 4-areally averaged temperature for 60-90 $\mathrm{N}$ latitude band (BEST, land + ocean, after Rohde et al. 2013, updated), Arctic 5- areally averaged temperature for 60-90 $\mathrm{N}$ latitude band (BEST, land only, after Rohde et al. 2013, updated), NH 1 (land + ocean) - areally averaged temperature for Northern Hemisphere (HadCRUT4, after Morice et al. 2012, updated), NH 2 (BEST, land + ocean) - areally averaged temperature for Northern Hemisphere (BEST, after Rohde et al. 2013, updated) markedly smallest warming occurred in the BAFR (only by $1.33^{\circ} \mathrm{C}$ ), although there was a similar pattern of changes in all seasons to that in the ATLR. It is, however, interesting to note that the summer SAT rise in the period 1996-2015 was greater in the BAFR than in the ATLR. Of all the climatic regions, the BAFR saw the greatest rate of winter and spring warming in the most recent two decades in comparison to the CGW period (Table 2).

The spatial distribution of seasonal and annual anomalies of SAT in the HA in the RRAW period relative to the period 1951-1990 is shown in Fig. 4. Annual SAT anomalies exceed $1.5^{\circ} \mathrm{C}$ in almost the entire Arctic, except southern continental and coastal parts of the Eurasian continent and southern areas stretching from Hudson Bay to Jan Mayen Island. The greatest warming $\left(>2.5{ }^{\circ} \mathrm{C}\right)$ was observed between Svalbard and Franz Joseph Land. This area also had the greatest winter warming $\left(>3.5^{\circ} \mathrm{C}\right)$ and spring warming $\left(>2.5^{\circ} \mathrm{C}\right)$ (Fig. 4). The great winter warming in this area was also more recently noted among others by Alexeev et al. (2017), Jung et al. (2017) and Kohnemann et al. (2017). Graham et al. (2017) found that, in the period of interest, a significantly greater frequency and duration of Arctic winter warming events (see their Fig. 3c) was observed, and in particular after 2004. Thus, one reason for this warming was the change in atmospheric circulation towards a greater frequency of inflow of warm air masses from the south to the Barents Sea (Simmons and Poli 2015; Alexeev et al. 2017; Yurova et al. 2018). Several other driving factors should also be mentioned, such as the welldocumented retreat of Arctic sea ice in this time (increased absorption of solar radiation by water newly free of sea ice, Perovich et al. 2008), in particular large in the Barents-Kara seas, being the effect of significant inflow of oceanic heat (increase of advection and temperature of the Atlantic water, Walczowski et al. 2012; Jung et al. 2017). In autumn, the greatest warming occurred over the Arctic Ocean $\left(>2.5^{\circ} \mathrm{C}\right)$ with the maximum in its central part $\left(>3.0^{\circ} \mathrm{C}\right)$, while the smallest usually occurred in areas lying near the southern boundary of the HA. Warming was most evenly distributed in summer, and as a result, anomalies range mostly around $1.0{ }^{\circ} \mathrm{C}$ (Fig. 4).

Since about the mid-1990s, the rate of warming in the HA has become greater than the increasing rate of SAT in the $\mathrm{NH}$ (Fig. 5). Earlier, such a situation occurred in the 1950s, the period ending the warming phase of the Arctic which began in the 1920s (the so-called early twentieth century warming). In the twenty-first century, the SAT in the HA reached and even exceeded the level of the warming that occurred in the 1930s and 1940s - the greatest warming of the twentieth century. In this 15 -year period, the rate of warming in the HA is slightly more than twice as great as in the NH. It is interesting to note that together with the warming, a decrease in variability of both seasonal and annual means of SAT is observed (Table S3). The greatest SAT decrease in variability between the periods 1951-2015 and 1996-2015 occurred in spring and 

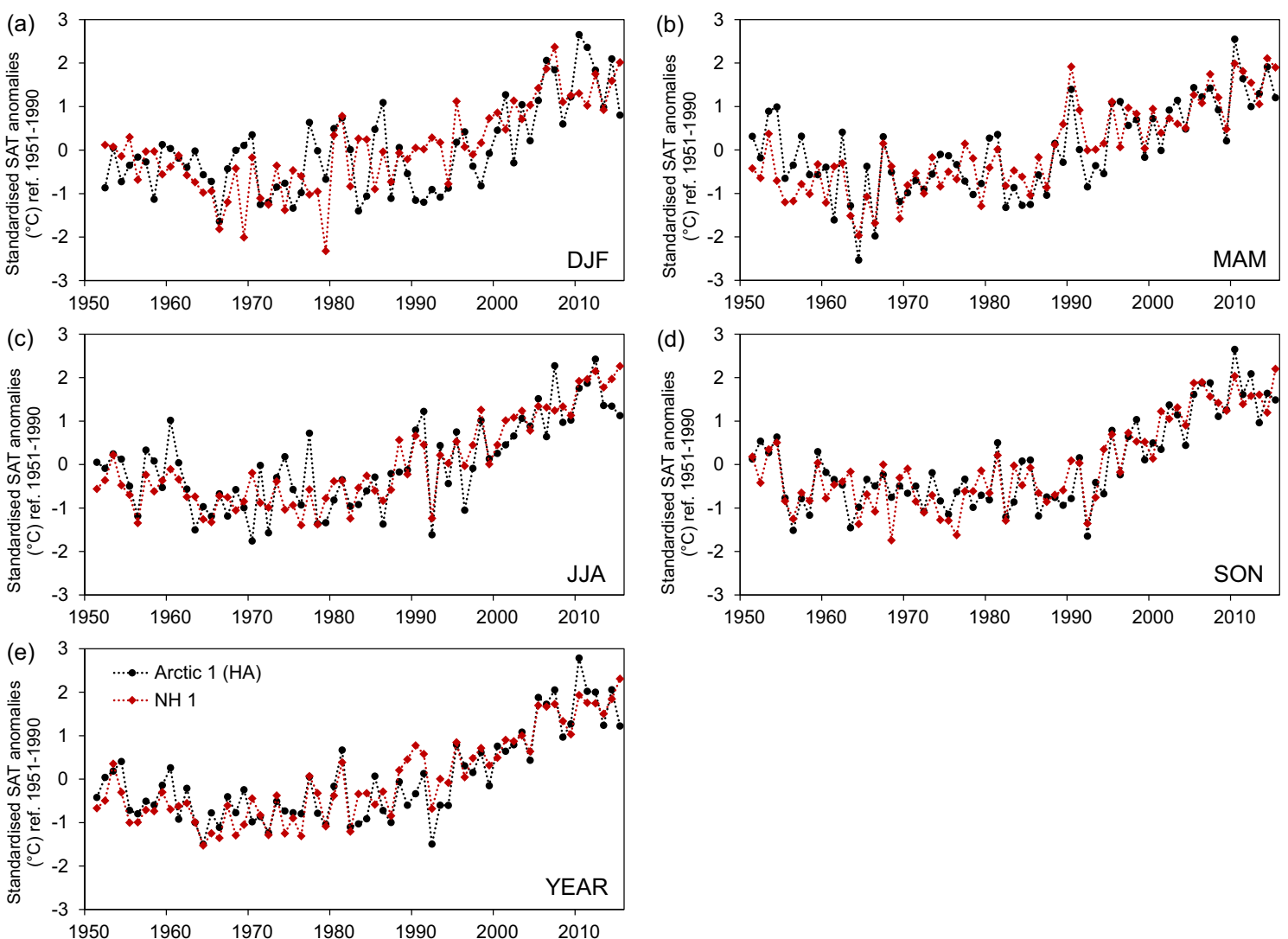

Fig. 3 Standardised a-d seasonal and e annual SAT anomalies $\left({ }^{\circ} \mathrm{C}\right.$, relative to 1951-1990 mean) in the Arctic (Arctic 1, dots) and the Northern Hemisphere (NH 1, squares) over the period 1951-2015. Key:

autumn (by $0.3{ }^{\circ} \mathrm{C}$ for HA). A decrease in variability between these periods was noted also for the NH (Table S3). The best fit with observational data (Arctic 1) is provided by Arctic 3 (CRUTEM4, land only), whereas Arctic 5 (BEST, land only) underestimates recent warming for the whole Arctic (Fig. 5), similarly as was revealed for northern Canada (Way et al. 2017).

In the RRAW period, very large increases in both seasonal and annual means were observed in the ATLR and the Siberian region (hereinafter SIBR), while in the rest of the Arctic, the rate of warming was usually weaker than trends for the CGW period. In particular, there was a large fall in the rate of warming in spring, with near-zero trends (BAFR and CANR) and even a negative trend $\left(-0.34{ }^{\circ} \mathrm{C} / 10\right.$ years $)$ in the Pacific region (hereinafter PACR) (Table 3). In the entire study period (1951-2015), all seasonal and annual trends in all climatic regions and for the entire HA are positive and, except for winter and spring in the BAFR, statistically significant. The greatest rate of warming in this time occurred in winter and autumn $\left(0.38^{\circ} \mathrm{C} / 10\right.$ years $)$, while the smallest was in summer $\left(0.19^{\circ} \mathrm{C} / 10\right.$ years) (Table 3$)$. The PACR saw the greatest warming $\left(0.39^{\circ} \mathrm{C} / 10\right.$ years $)$, while the smallest was in the BAFR (only $0.17^{\circ} \mathrm{C} / 10$ years). Magnitudes of trends of mean annual SAT for the HA for the three analysed periods

Arctic 1 - areally averaged temperature based on data from 37 Arctic stations, NH 1 (land + ocean) - areally averaged temperature for Northern Hemisphere (HadCRUT4, after Morice et al. 2012, updated)

(1951-2015, 1976-2015 and 1996-2015) show significant increasing values, from $0.32{ }^{\circ} \mathrm{C} / 10$ years for the first period, through $0.68{ }^{\circ} \mathrm{C} / 10$ years in the second period, to $0.86{ }^{\circ} \mathrm{C} /$ 10 years for the last period (Table 3 ). The greatest trend intensification between the first and the later periods occurred in winter (3.6 times) and summer (3.3 times). It is interesting to note that SAT trends in the NH increased significantly between the periods 1951-2015 and 1976-2015, but then show a small decrease from $0.24-0.26^{\circ} \mathrm{C} / 10$ years (1976-2015) to $0.22-0.25^{\circ} \mathrm{C} / 10$ years $(1996-2015)$. As a result, PA (calculated here as the ratio between annual SAT trends) almost doubled, from 2.4 in 1951-2015 to 3.9 in 1996-2015 (see PA3 in Table 1). It is also interesting to note that lands in the northern latitudes (Arctic 3) show almost the same rate of warming in the periods 1951-2015 and 1976-2015 as those in HA, while in the period 1996-2015, they display an even greater one. When ocean areas are included (Arctic 2), SAT trends in the HA in all study periods (particularly in the period 1976-2015) are markedly greater than those calculated for the Arctic 2 (see Table 3).

The inclusion of the data from the period 2011-2015 in the calculations changed the trends of areally averaged SAT for all the Arctic and for individual climatic regions (Table S2). Generally, trends are greatest in the period 1951-2015 in 


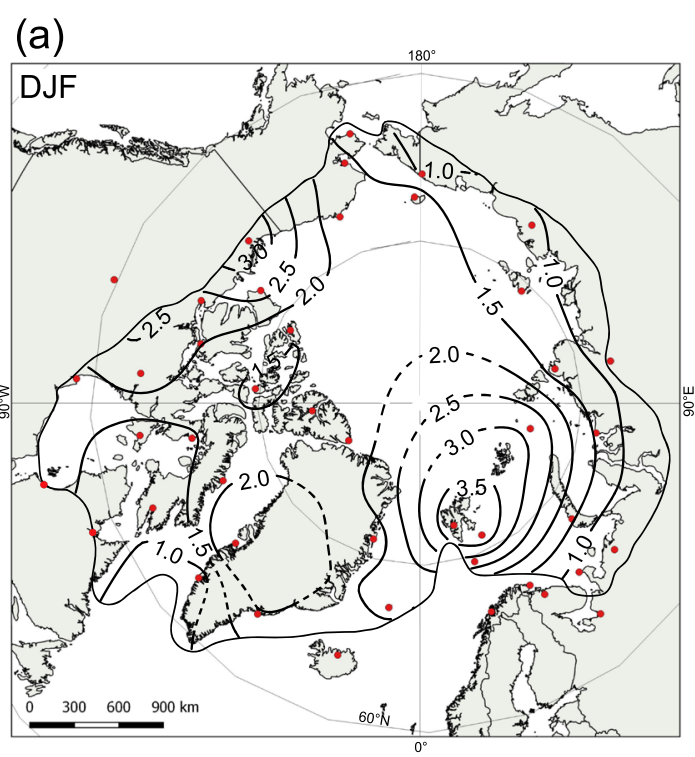

(c)

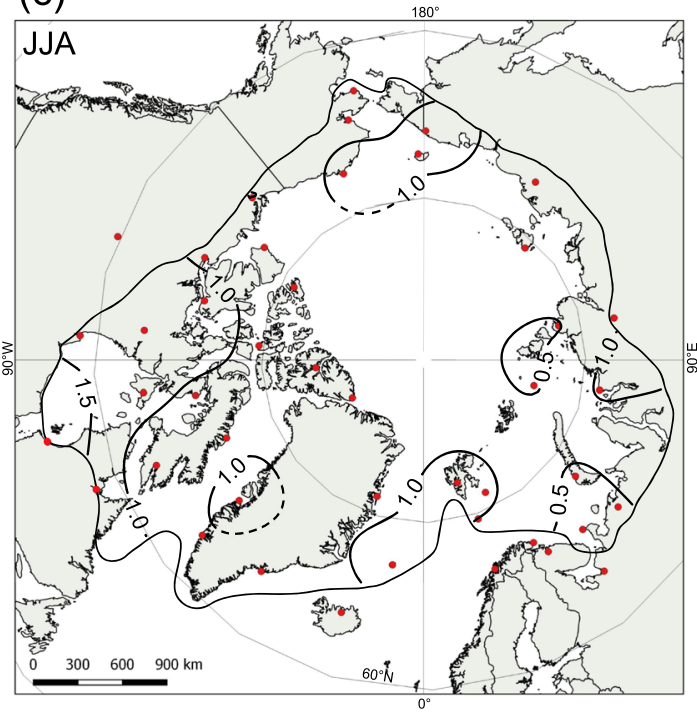

(e)

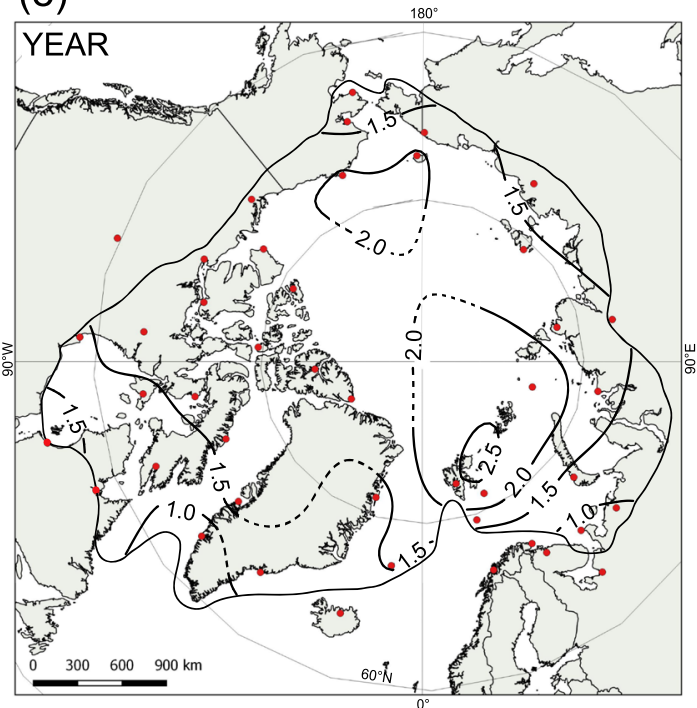

(b)

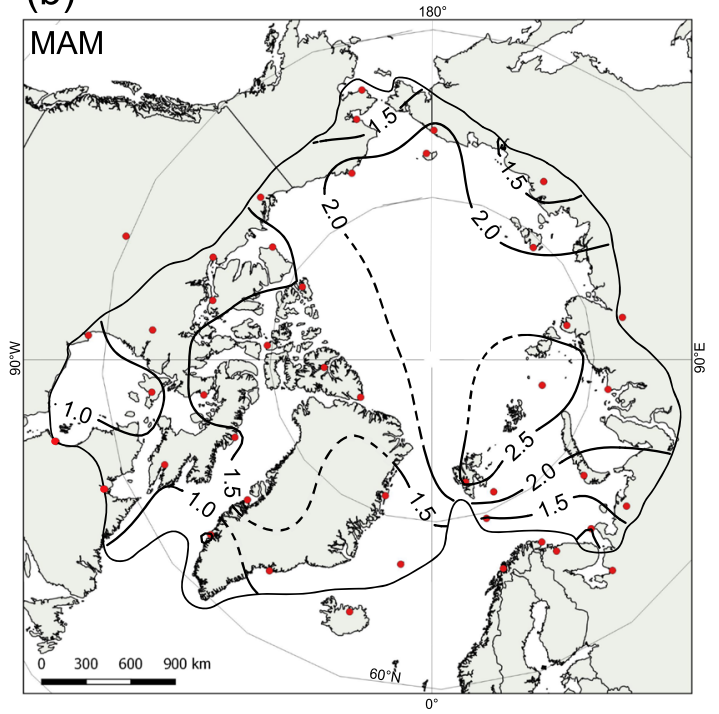

(d)

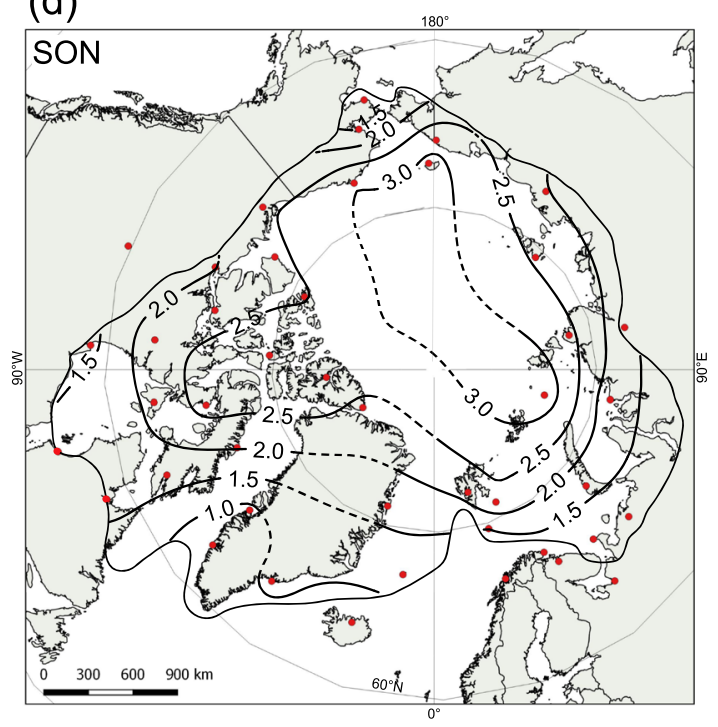




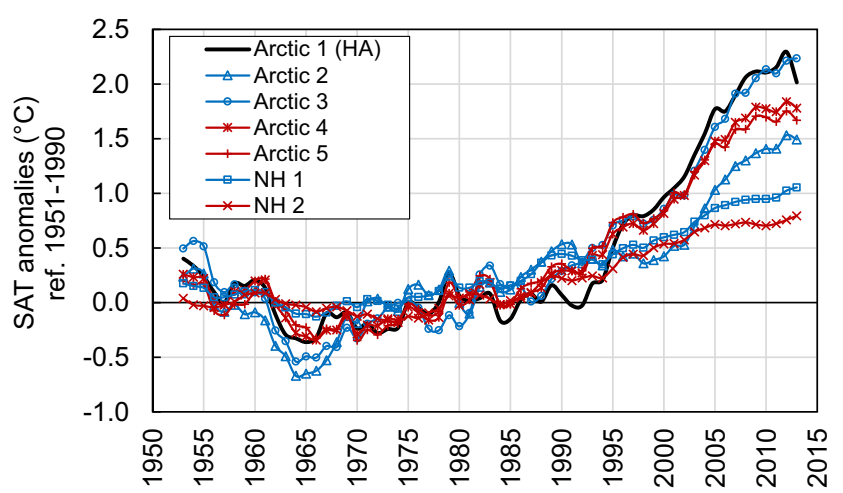

Fig. 5 Running 5-year mean annual SAT anomalies $\left({ }^{\circ} \mathrm{C}\right.$, relative to $1951-$ 1990 mean) in the Arctic (Arctic 1, Arctic 2, Arctic 3, Arctic 4 and Arctic 5 ) and the Northern Hemisphere (NH 1 and NH 2) over the period 19512015. Key: Arctic 1 - areally averaged temperature based on data from 37 Arctic stations, Arctic 2 - areally averaged temperature for $60-90^{\circ} \mathrm{N}$ latitude band (HadCRUT4, land + ocean, after Morice et al. 2012, updated), Arctic 3-areally averaged temperature for $60-90^{\circ} \mathrm{N}$ latitude band (CRUTEM4, land only, after Jones et al. 2012, updated), Arctic 4 - areally averaged temperature for $60-90^{\circ} \mathrm{N}$ latitude band (BEST, land + ocean, after Rohde et al. 2013, updated), Arctic 5-areally averaged temperature for $60-90^{\circ} \mathrm{N}$ latitude band (BEST, land only, after Rohde et al. 2013, updated), NH 1 (land + ocean) - areally averaged temperature for Northern Hemisphere (HadCRUT4, after Morice et al. 2012, updated), NH 2 (BEST, land + ocean) - areally averaged temperature for Northern Hemisphere (after Rohde et al. 2013, updated)

comparison to the five previously analysed shorter periods (1951-1990, 1951-1995, 1951-2000, 1951-2005 and 1951-2010). Such a pattern of steady increase in magnitudes of trends, when 5-year series of data were successively added, is particularly well seen for the HA as a whole both for its annual and seasonal values, except for winter, when the downward trend of SAT was greater in 1951-1995 than in 19511990 (Table S2). In all climatic regions, such a steady rising tendency of SAT is also observed almost constantly for annual values and for autumn. In summer and winter, rising magnitudes of trends are noted in almost all climatic regions, except PACR, while SAT trends in the period 1951-2015 are greatest in spring only in ATLR and SIBR (Table S2). The greatest change in trends in the six study periods was noted in the BAFR. Until 2000, trends here were downward and even statistically significant in some seasonal and annual values. Upward trends in all seasons for the period 1951-2010 were noted for the first time here but were statistically significant only in autumn. In 1951-2015, statistically significant trends were also calculated for summer and for the year (Table S2).

In the period 1951-2015, trends in SAT in the HA were positive throughout the research area (Table 3, Fig. 6). The greatest increases in mean annual SAT $\left(0.4-0.5^{\circ} \mathrm{C} / 10\right.$ years $)$ occurred mainly over the Arctic Ocean, northern Alaska with the Beaufort Sea and the area stretching from Svalbard to Severnaya Zemlya, but with a maximum $\left(>0.5^{\circ} \mathrm{C} / 10\right.$ years $)$ over Svalbard (Fig. 6). Trends smaller than $0.3^{\circ} \mathrm{C} / 10$ years are only noted in a small fragment of the European Arctic, but mainly in the southern parts of Greenland, BAFR and Baffin Island, as well as over the Hudson Bay area. In comparison to the period 1951-2010, in the study period, the rate of warming increased by about $0.1{ }^{\circ} \mathrm{C} / 10$ years mainly in the ATLR and SIBR, while in other parts of the Arctic, smaller increases or no change in trends was noted (compare Fig. 10.17 in Przybylak 2016 with Fig. 6). Thus, geographically, the largest trends moved from being in the PACR and western CANR in 1951-2010 to being in north-eastern ATLR (and particularly to the region between Svalbard, Franz Joseph Land and Novaya Zemlya) in 1951-2015. The spatial pattern of SAT trends in the HA is now closer to future climate scenarios, which locate greatest warming in the latter area (see Koenigk et al. 2013 or Fig. 11.15 in Przybylak 2016). The markedly greatest areally averaged rate of warming in the annual cycle was noted in the cold half-year. However, only in winter between Svalbard and Franz Joseph Land and over north-eastern Alaska were SAT trends greater than $0.7^{\circ} \mathrm{C} /$ 10 years observed (Fig. 6). The smallest trends in this season $\left(<0.4{ }^{\circ} \mathrm{C} / 10\right.$ years $)$ occurred in continental parts of the Eurasian Arctic and southern parts of seas neighbouring them, as well as in southern parts of Greenland and BAFR and south-eastern CANR. Autumn is a second season which had the same average rate of warming as winter $\left(0.38^{\circ} \mathrm{C} / 10\right.$ years, see Table 3$)$. The greatest SAT increase $\left(>0.5^{\circ} \mathrm{C} / 10\right.$ years $)$ occurred mainly over the Arctic Ocean and the northern part of the CANR, while the smallest $\left(<0.2^{\circ} \mathrm{C} / 10\right.$ years $)$ occurred over southern Greenland and surrounding seas on both sides (Fig. 6). Of all seasons, in accordance with expectations, the smallest increase in SAT in 1951-2015 (from $0.1^{\circ} \mathrm{C} / 10$ years to $0.3{ }^{\circ} \mathrm{C} / 10$ years) was noted in summer. The largest warming $\left(>0.2{ }^{\circ} \mathrm{C} / 10\right.$ years) occurred in the area stretching from Chukotka Peninsula to Labrador Peninsula, while the smallest $\left(<0.1^{\circ} \mathrm{C} / 10\right.$ years $)$ was in separate areas located in Greenland, Baffin Land and Severnaya Zemlya (Fig. 6).

From the results presented above, we can conclude that the slowdown in SAT trends in the recent two decades (also described often as a warming "hiatus"), noted for NH (IPCC 2013; Fyfe et al. 2016), is not present in the entire HA (see Arctic 1-Arctic 5 in Table 3). On the other hand, a clear slowdown in SAT trends is observed in the period 19962015 in the Pacific region (in comparison to the period 1976-2015), and in particular in the Canadian region, where SAT trends in recent period are the smallest $\left(0.29^{\circ} \mathrm{C} / 10\right.$ years versus $0.61{ }^{\circ} \mathrm{C} / 10$ years [1976-2015] and $0.34{ }^{\circ} \mathrm{C} / 10$ years [1951-2015]). Karl et al. (2015) reveal that global trends are higher than those reported by the IPCC (2013), especially in recent decades, and that the SAT trend in 2001-2015 is the same as in 1951-2000. Thus, according to them, this excludes the existence of a "slowdown" in global SAT. In conclusion, we must say that the discussion is still open concerning the existence or non-existence of a "hiatus" in global SAT in the recent two decades. 
Table 3 Seasonal and annual SAT trends $\left({ }^{\circ} \mathrm{C}\right.$ decade $\left.^{-1}\right)$ in the Arctic

\begin{tabular}{|c|c|c|c|c|c|c|c|c|c|c|c|c|c|c|c|}
\hline \multirow[t]{3}{*}{ Area } & \multicolumn{15}{|c|}{ Trends ${ }^{\circ} \mathrm{C} / 10$ years } \\
\hline & \multicolumn{5}{|c|}{ 1951-2015 } & \multicolumn{5}{|c|}{ 1976-2015 } & \multicolumn{5}{|c|}{ 1996-2015 } \\
\hline & DJF & MAM & JJA & SON & YEAR & DJF & MAM & JJA & SON & YEAR & DJF & MAM & JJA & SON & YEAR \\
\hline ATLR & 0.46 & 0.45 & 0.17 & 0.32 & 0.35 & 1.24 & 0.80 & 0.42 & 0.77 & 0.81 & 2.59 & 1.38 & 0.62 & 1.08 & 1.40 \\
\hline SIBR & 0.31 & 0.48 & 0.15 & 0.50 & 0.36 & 0.57 & 1.02 & 0.42 & 1.23 & 0.83 & 1.53 & 2.07 & 0.92 & 2.25 & 1.67 \\
\hline PACR & 0.48 & 0.37 & 0.26 & 0.45 & 0.39 & 0.43 & 0.56 & 0.26 & 0.86 & 0.51 & 1.42 & -0.34 & 0.45 & 0.80 & 0.56 \\
\hline CANR & 0.41 & 0.25 & 0.23 & 0.44 & 0.34 & 0.60 & 0.53 & 0.46 & 0.89 & 0.61 & 0.63 & 0.03 & 0.34 & 0.38 & 0.29 \\
\hline BAFR & 0.26 & 0.08 & 0.16 & 0.20 & 0.17 & 0.81 & 0.61 & 0.61 & 0.59 & 0.64 & 0.74 & 0.00 & 0.79 & 0.21 & 0.37 \\
\hline Arctic 1 (HA) & 0.38 & 0.33 & 0.19 & 0.38 & 0.32 & 0.73 & 0.70 & 0.43 & 0.87 & 0.68 & 1.38 & 0.63 & 0.62 & 0.94 & 0.86 \\
\hline Arctic 2 (land + ocean) & 0.30 & 0.31 & 0.20 & 0.21 & 0.24 & 0.63 & 0.42 & 0.40 & 0.48 & 0.38 & 1.25 & 0.69 & 0.64 & 0.46 & 0.74 \\
\hline Arctic 3 (land only) & 0.38 & 0.40 & 0.17 & 0.37 & 0.33 & 0.80 & 0.72 & 0.38 & 0.84 & 0.69 & 1.61 & 0.94 & 0.50 & 1.05 & 1.00 \\
\hline Arctic 4 (land + ocean) & 0.35 & 0.34 & 0.14 & 0.32 & 0.29 & 0.61 & 0.62 & 0.33 & 0.74 & 0.58 & 1.07 & 0.65 & 0.43 & 0.90 & 0.74 \\
\hline Arctic 5 (land only) & 0.35 & 0.34 & 0.16 & 0.31 & 0.29 & 0.54 & 0.57 & 0.35 & 0.64 & 0.53 & 0.87 & 0.57 & 0.42 & 0.69 & 0.61 \\
\hline NH 1 (land + ocean) & 0.13 & 0.15 & 0.13 & 0.14 & 0.14 & 0.21 & 0.24 & 0.25 & 0.26 & 0.24 & 0.10 & 0.22 & 0.24 & 0.29 & 0.22 \\
\hline NH 2 (land + ocean) & 0.15 & 0.16 & 0.12 & 0.15 & 0.15 & 0.25 & 0.26 & 0.24 & 0.30 & 0.26 & 0.18 & 0.24 & 0.23 & 0.33 & 0.25 \\
\hline
\end{tabular}

Key: Arctic 1-areally averaged temperature based on data from 37 Arctic stations, Arctic 2 - areally averaged temperature for $60-90^{\circ} \mathrm{N}$ latitude band (HadCRUT4, land + ocean, after Morice et al. 2012, updated), Arctic 3-areally averaged temperature for 60-90 $\mathrm{N}$ latitude band (CRUTEM4, land only, after Jones et al. 2012, updated), Arctic 4 - areally averaged temperature for 60-90 $\mathrm{N}$ latitude band (BEST, land + ocean, after Rohde et al. 2013, updated), Arctic 5-areally averaged temperature for 60-90 $\mathrm{N}$ latitude band (BEST, land only, after Rohde et al. 2013, updated), NH 1 (land + ocean) areally averaged temperature for Northern Hemisphere (HadCRUT4, after Morice et al. 2012, updated), NH 2 (BEST, land + ocean) - areally averaged temperature for Northern Hemisphere (BEST, after Rohde et al. 2013, updated). Trends statistically significant at the level 0.05 are shown in italics

\subsection{Reanalyses}

In the slightly more than 20-year period of availability of reanalysis products (starting from Kalnay et al. 1996; Kistler et al. 2001), they have developed significantly, as has their use in climate and climate change analyses. Also for the Arctic, which is the area of analysis presented in present paper, there are quite a lot of papers evaluating the possibility of using reanalyses to study climate and climate change in the region (see, e.g. Vízi and Przybylak 2006; Bromwich et al. 2007; Jakobson et al. 2012; Przybylak et al. 2013, 2016; Lindsay et al. 2014; Rapaić et al. 2015; Way and Bonnaventure 2015; Cullather 2017; Diaconescu et al. 2017; Wegmann et al. 2017; Klaus et al. 2018). The relative advantage of using reanalysis products for the Arctic and also the Antarctic, as opposed to using them for lower latitudes, results from the fact that in polar regions the network of meteorological stations is significantly sparser than at lower latitudes, while, due to the common presence of cryosphere in different forms (from ice sheets to sea ice), the processes are more complicated. The history of development of reanalysis products is extremely dynamic; see for example the review by Lindsay et al. (2014) or Fujiwara et al. (2017), which also gives a short description of the majority of recent versions of reanalyses, including data coverage (see also Section 2 in the present paper). Recently, a very good and comprehensive overview of the significance of reanalyses for climate sciences has also been presented by Cullather et al.
(2016) in the white paper entitled: Systematic Improvements of Reanalyses in the Arctic (SIRTA).

Having good quality SAT data for the HA for the period 1951-2015, we decided to use the newest versions of reanalysis products to check if their present quality is better than when older versions were utilised. For example, Vízi and Przybylak (2006) showed that NCEP/NCAR (i.e. NCEP-R1) reanalysis SAT values (1961-1990) for the Canadian Arctic $\left(\right.$ area $>55^{\circ} \mathrm{N}$ ) were, for the majority of months (except March-June), more than $2{ }^{\circ} \mathrm{C}$ lower (in October and November even more than $5{ }^{\circ} \mathrm{C}$ lower) than SAT data from the Global Historical Climatology Network (GHCN) and Adjusted Historical Canadian Climate Database (AHCCD). The recent analysis made by Lindsay et al. (2014) for the whole Arctic defined as latitude band $60-90^{\circ} \mathrm{N}$ (period 1980-2009) using the NCEP/NCAR and NCEP/DOE reanalyses (i.e. NCEP-R1 and NCEP-R2, respectively) reveals smaller biases (negative -1.5 to $-2{ }^{\circ} \mathrm{C}$ for AprilOctober and small positive for winter months) than that presented by Vízi and Przybylak (2006). Lindsay et al. (2014) also documented that three other reanalyses (CFSR, MERRA and JRA-25) have biases ranging usually between -1 and $1{ }^{\circ} \mathrm{C}$. They also found such small biases from May to October for the $20 \mathrm{CR}$, but winter months are $4-6{ }^{\circ} \mathrm{C}$ warmer than observations taken from the Climate Research Unit (Brohan et al. 2006). All reanalysis products used by Lindsay et al. (2014) show a warming bias in winter, while 


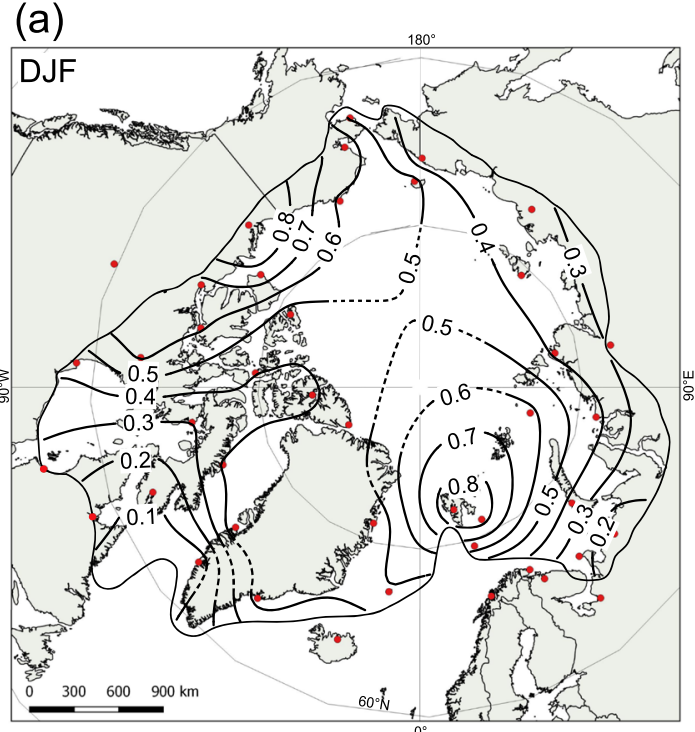

(c)

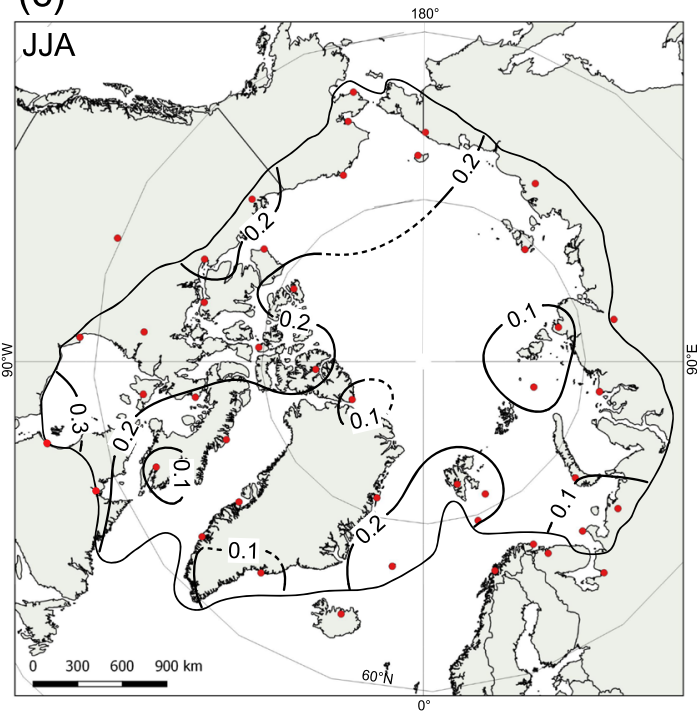

(e)

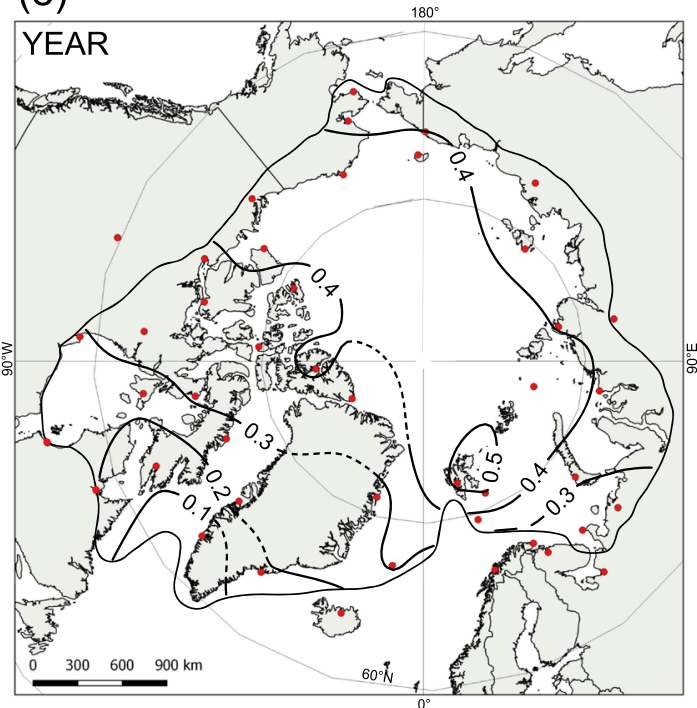

(b)

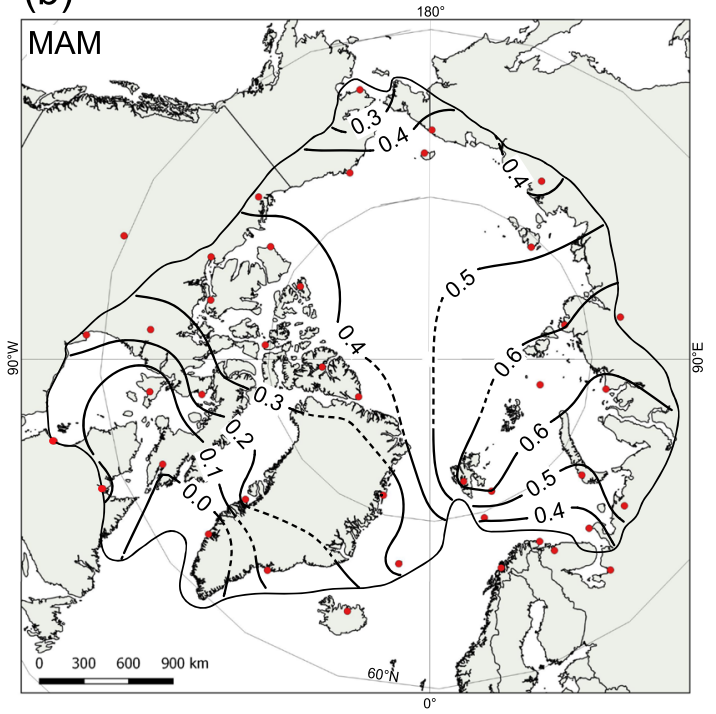

(d)

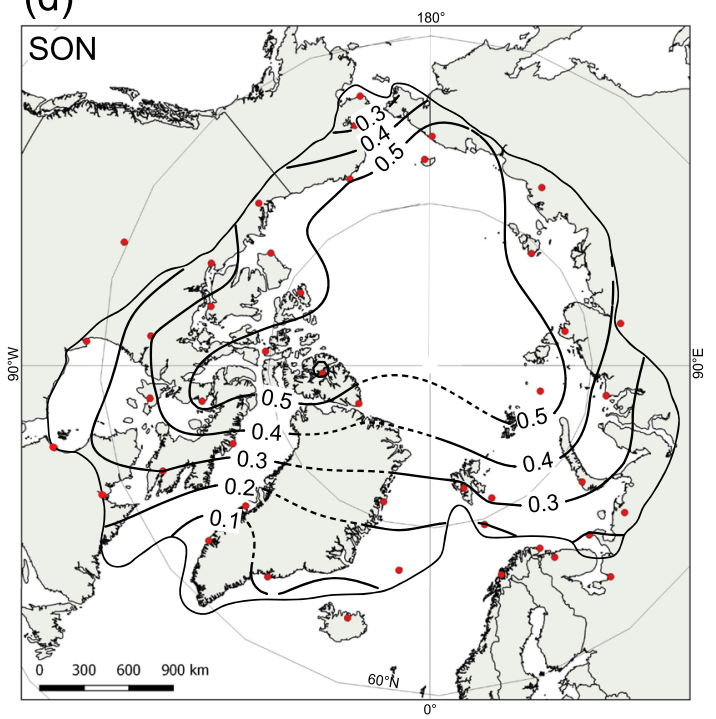


in the rest of the year, there is mainly a negative bias (see their Figure 1b). On the other hand, Liu et al. (2008) found a warming bias in mean annual values using reanalyses NCEP-R1 and ERA-40. Warming biases for summer and winter for the Canadian Arctic (except Baffin Island) for 1980 2004 using five global reanalysis products (ERA-Int, JRA-55, MERRA, CFSR and GMFD) are also presented by Diaconescu et al. (2017). Way and Bonnaventure (2015) found that mean absolute errors between observational and reanalyses data for the Labrador-Ungava region are \pm 1 and $\pm 0.5^{\circ} \mathrm{C}$ on monthly and annual timescales, respectively. They estimated that the ERA-Interim (ERA-Int) and Modern-Era Retrospective Analysis for Research and Applications (MERRA) reanalyses are the most suitable for filling gaps in the observational data, i.e. both reanalyses are close to observations in the region they studied.

In the present paper, reanalysis products are compared with observations for mean annual and seasonal values (with analysis also for sub-periods), and not only for the entire HA, but also for the five distinguished climatic regions. Changes in the year-to-year run of mean annual SAT values taken from different reanalyses and observations are analysed for the entire HA (Fig. 7) and for climatic regions (not shown). It is very clearly seen that there is quite a good fit between data from reanalyses and observations, in particular after 1979, when satellite data were incorporated for reanalyses. Average annual values from all available reanalyses and observations shown in Fig. 7b, and also for seasons in Table 4, reveal mean biases of less than $\pm 0.2^{\circ} \mathrm{C}$ for the period $1951-2015$. In the cold half-year, reanalyses are too cold (by $0.2{ }^{\circ} \mathrm{C}$ ), while in summer, the fit is perfect. The worst results were received for the first period (1951-1957) and the last (2011-2015), when differences in all seasons (except summer) range between -0.4 and $-0.9^{\circ} \mathrm{C}$. The great bias in the first period can be attributed to availability of only two reanalysis products $(20 \mathrm{CR}$ and CERA-20C), which assimilated only surface data, i.e. SLP, SST-Sea Ice and wind. We did not expect such large biases for the latter period. Analysis showed that negative large biases calculated for this period were caused mainly by the negative biases observed in MERRA-2 after 2005 (Fig. 7), which were particularly large in the CANR and SIBR (Fig. 8). This is probably connected with the fact that in the MERRA-2 product, in comparison to the previous version described as MERRA, a significant amount of new satellite data was assimilated (see Fig. 1 in McCarty et al. 2016 or https://gmao.gsfc.nasa.gov/research/science_snapshots/ MERRA2_obs_sys_ts.php). The greater spread between data from reanalyses in the Canadian Arctic in this time was also noted by Rapaić et al. (2015). They wrote that "Declining station networks, increased automation, and the inclusion of new satellite data streams in reanalyses are potential contributing factors to this phenomenon." On the other hand, Cullather et al. (2017) found that the MERRA-2 reanalysis shows a better fit with observations (period 2008-2012) over central Greenland (Summit Station, $73^{\circ} \mathrm{N}, 38^{\circ} \mathrm{W}$ ) than the five other reanalyses used by them. Also opposite to our results are the signs of differences: outside Greenland the biases are negative, while in central Greenland, they are such only in summer. In the latter area, positive biases dominate, ranging mainly between 1 and $2{ }^{\circ} \mathrm{C}$ (see Fig. 4 in Cullather et al. 2017).

A large improvement in the quality of reanalyses data in comparison to observations can be observed for the period 1958-1978, when, instead of separate data from reanalyses, their mean values are used (compare a with $b$ of Fig. 7). The best fit between mean annual values of SAT in the HA taken from reanalyses and observations is for 1979-2010 (see Fig. 7). The seasonal and annual mean values of differences calculated as the mean of the six available reanalyses on the one hand and mean observations on the other are $0.0^{\circ} \mathrm{C}$ (Table 4). Generally, a very good correspondence between year-to-year courses of mean annual and seasonal SAT between reanalyses and observations is also seen when data are averaged for the climatic regions (not shown). The worst fit is most often observed for the BAFR, particularly in the cold half-year and before 1979.

Detailed analyses of differences for all reanalysis products using mean annual 10-year values are presented in Fig. 8 for the entire HA and all climatic regions and in Fig. 9 for all seasons, but only for the entire HA. On the other hand, results of calculations of differences for all climatic regions and all seasons are shown in Fig. S1. Again, it is clearly seen that including satellite data in the reanalyses markedly improved their quality and reliability. However, the attached documentation also allows us to check which reanalysis products show the best fit with data taken from observations and which show the worst. In the pre-satellite period, JRA-55 and 20CRv2c products usually have negative and positive biases, respectively. Thus, it seems to be a reasonable solution to use average values (both for the entire HA and for all climatic regions) from both reanalyses for this period (see Figs. 8 and 9, Fig. $\mathrm{S} 1$ ), in particular for winter and autumn. In summer, biases are rather small (usually for the entire HA and for most of the climatic regions, except the CANR, they are lower than \pm $0.3{ }^{\circ} \mathrm{C}$ ). Relatively small biases have also been observed in spring, when for the entire HA the range of $\pm 0.5{ }^{\circ} \mathrm{C}$ was exceeded only in the decade 1951-1960 for data from 20CRv2c (Fig. 9). In data averaged for climatic regions, biases in this season rarely exceed $1.0^{\circ} \mathrm{C}$ (Fig. S1). In the satellite period, biases calculated for seasons and all studied regions are very small and usually lower than $\pm 0.3{ }^{\circ} \mathrm{C}$, except for data taken from MERRA-2 (Figs. 8 and 9, Fig. S1). Large cold biases of SAT values taken from MERRA-2 for the period 2001-2015 are generally observed in all seasons (except summer) and also in all climatic regions. 

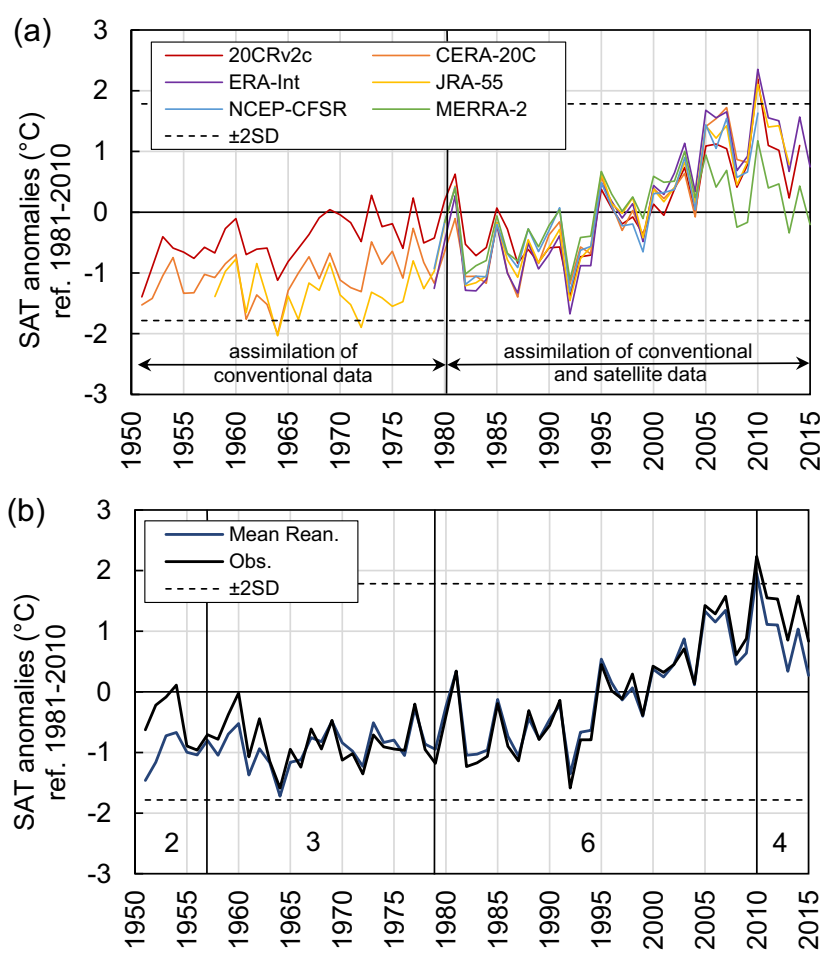

Fig. 7 Year-to-year courses of annual SAT anomalies $\left({ }^{\circ} \mathrm{C}\right.$, relative to 1981-2010 mean) in the Arctic in 1951-2015 based on a individual reanalyses and $\mathbf{b}$ mean reanalysis and observations. Dashed lines indicate \pm 2 SD of SAT $\left({ }^{\circ} \mathrm{C}\right)$ calculated for observational data from 1951 to 2015. Digits shown on sub-figure (b) indicate the number of reanalyses taken for averaging in particular periods: 1951-1957, 1958-1978, 1979-2010, 2011-2015

To estimate which reanalysis products are the best in comparison to SAT observations from the HA, correlation coefficients $(r)$ and RMSE statistics have been calculated based on data from the period 1981-2010, for which reanalyses have available data (see Fig. 10). The results again confirm that using mean values from all available reanalyses is the best solution to study climate and climate change aspects in the HA. Coefficients of correlation both for mean annual and seasonal values for the entire HA are close to $r=1.00$ and the RMSE is below $0.1{ }^{\circ} \mathrm{C}$ for annual and summer means, slightly above $0.1{ }^{\circ} \mathrm{C}$ for spring and near $0.2^{\circ} \mathrm{C}$ (for autumn

Table 4 Differences in seasonal and annual SAT anomalies $\left({ }^{\circ} \mathrm{C}\right.$, relative to 1981-2018 mean) between mean reanalysis and observations in the Arctic in selected periods

\begin{tabular}{lrrrrr}
\hline Period & DJF & MAM & \multicolumn{1}{c}{ JJA } & SON & Year \\
\hline $1951-2015$ & -0.2 & -0.1 & 0.0 & -0.2 & -0.1 \\
$1951-1957$ & -0.6 & -0.7 & -0.1 & -0.6 & -0.5 \\
$1958-1978$ & -0.2 & 0.1 & 0.1 & -0.3 & -0.1 \\
$1979-2010$ & 0.0 & 0.0 & 0.0 & 0.0 & 0.0 \\
$2011-2015$ & -0.9 & -0.6 & -0.2 & -0.4 & -0.5 \\
\hline
\end{tabular}

These differences were obtained by subtracting observational data from mean reanalysis values and in particular winter) (see Fig. 10). Cullather et al. (2017) investigated average annual SAT cycle in the area $60-90^{\circ} \mathrm{N}$ using 10 reanalysis products for the common period 1980 1993 and also found that biases are the greatest in winter months. In accordance with expectations, for climatic regions, the above statistics are slightly worse than for the entire HA, but still very good. Correlation coefficients never fall below $r=0.9$ and occur below $r=0.95$ only once-in winter in SIBR. For individual reanalyses (excluding the three starred reanalyses also calculated for before the satellite era), correlation coefficients never fall below $r=0.8$ for the entire HA (Fig. 10) and, in the case of climatic regions, only for MERRA-2 for winter (not shown). The best fit with observations was found for data taken from JRA-55 and ERA-Int and the worst from MERRA-2. It is clear how assimilation of satellite data improved quality of reanalyses when we compare the above statistics for the same reanalysis products (20CRv2c, CERA20C and JRA-55) for the two periods 1981-2010 and 1958-1980 (see Fig. 10). When pre-satellite data are included, correlation coefficients are usually $0.2-0.3$ lower than the same calculations made for 1981-2010, and RMSEs are about 2 times greater. Here we must stress that our results are only valid for SAT (i.e. 2-m air temperature) and cannot be utilised for the free atmosphere. Results presented by Jakobson et al. (2012) show that different sets of reanalyses show best fit with observations (the mean profile averaged over the 29 soundings up to $900 \mathrm{~m}$, see their Figure 2) in lower near-surface atmosphere (NCEP-CFSR, NCEP-DOE) and above $200 \mathrm{~m}$ (ERA-Int, MERRA). They also stated that none of the five reanalyses analysed by them was successful in reproducing the shape of the temperature profile.

In general, the results presented above are in line with the opinion of Serreze and Barry (2014) that, due to discrepancies in reanalyses, it is necessary to take under consideration many reanalysed data as an average in order to properly analyse the mean state of the Arctic climate system. That is why we present below the spatial distribution of differences between mean reanalyses data only and SAT observations in HA from the pre-satellite period (1951-1978, Fig. S2) and the satellite period (1979-2015, Fig. S3). Differences in annual and seasonal values of SAT are significantly greater in 1951-1978 than in 1979-2015. The second important feature between the study periods is the occurrence of different spatial distributions of biases (Figs. S2 and S3). In the pre-satellite period, annual biases range from $-0.5{ }^{\circ} \mathrm{C}$ (Svalbard, Franz Joseph Land and Novaya Zemlya and surroundings seas, as well as southern parts of Greenland and BAFR) to $0.5^{\circ} \mathrm{C}$ (north-eastern CANR). The reason probably lies in the inadequate reproducibility of reanalyses of vigorous and changeable atmospheric circulation and its influence on SAT in these areas. In 19792015 , mean reanalyses are slightly too cold, with a maximum $\left(-0.1{ }^{\circ} \mathrm{C}\right)$ in central SIBR and northern Greenland and northern CANR. In both periods, the greatest biases are 
Fig. 8 Decadal differences of annual SAT anomalies $\left({ }^{\circ} \mathrm{C}\right.$, relative to 1981-2010 mean) between observations and reanalyses in a-f the Arctic regions in 1951-2015. These differences were obtained by subtracting observational data from reanalysis values. Note that the last period includes a 15 -year mean
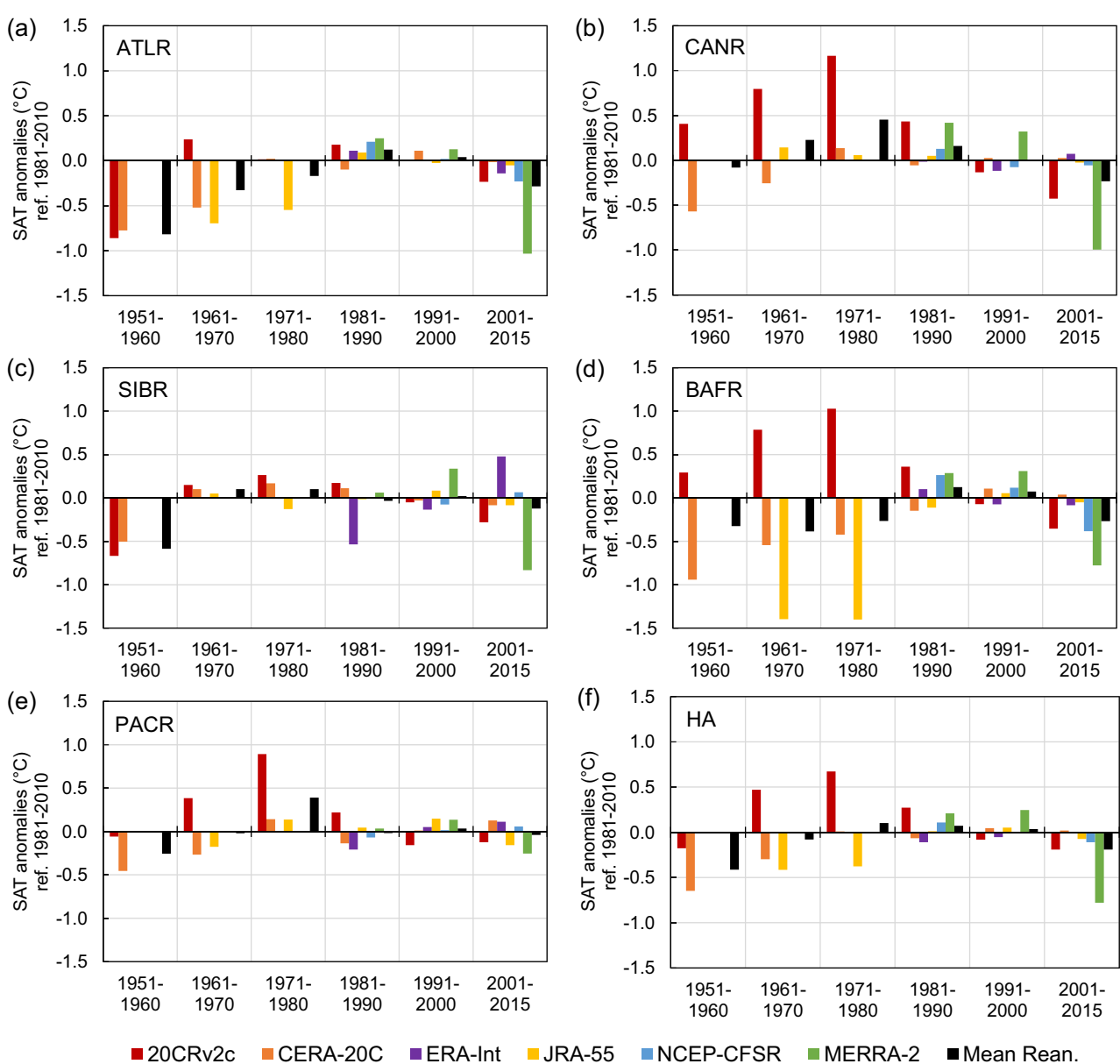

observed in winter, and the smallest in summer. In spring and autumn, they are more or less similar. Similar results were found by Way and Bonnaventure (2015) for the LabradorUngava region.
Fig. 9 Decadal differences in $\mathbf{a}-\mathbf{d}$ seasonal SAT anomalies $\left({ }^{\circ} \mathrm{C}\right.$, relative to $1981-2010$ mean) between observations and reanalyses in the Arctic in 19512015. These differences were obtained by subtracting observational data from reanalysis values. Note that the last period includes a 15-year mean
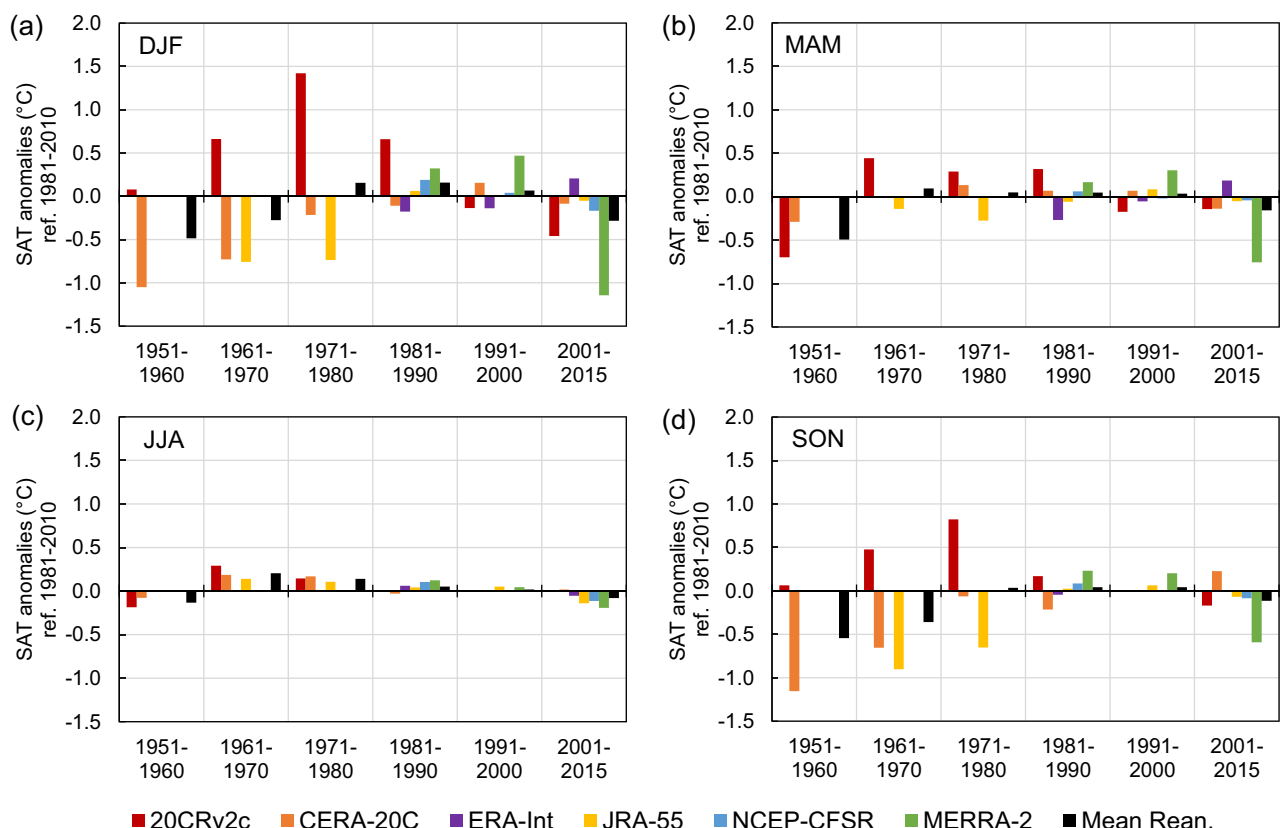
Fig. 10 a Correlation coefficients $(r)$ and $\mathbf{b}$ root mean square error (RMSE, ${ }^{\circ} \mathrm{C}$ ) of seasonal and annual values between individual reanalyses and observations for the common period of 1981-2010 in the Arctic. Asterisks indicate statistics for 1958-1980 for the three longest reanalyses (20CRv2c, CERA20C, JRA-55) which are performed by assimilation of conventional data only. All correlation coefficients are statistically significant at the level 0.05 (a)

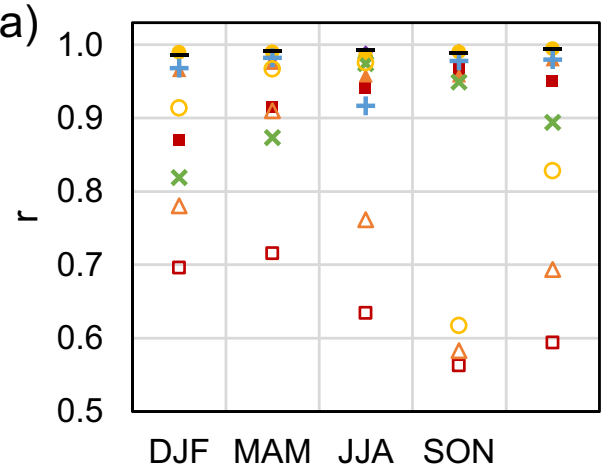

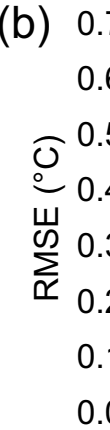

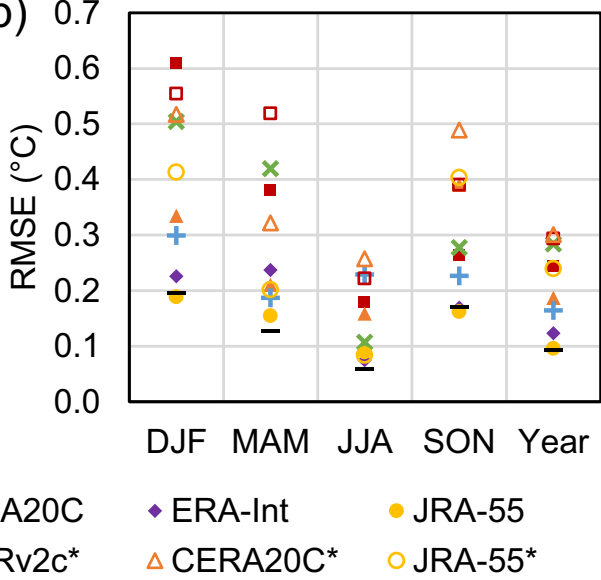

In winter, the greatest biases (usually double those of annual values) of SAT occurred in the same areas where they were also detected for the annual means (see Figs. S2 and S3). In summer, biases are close to $0.0^{\circ} \mathrm{C}$ across the entire area of HA, with the main exception of some areas in CANR. In both periods, positive biases were noted, reaching maximally $0.5-1.0^{\circ} \mathrm{C}$ in the presatellite period and only $0.05^{\circ} \mathrm{C}$ in the satellite period.
The magnitude of biases connected with calculations of SAT trends for the three study periods using averaged data from all available reanalyses is shown in Table 5 (left part). For the entire HA, trends for mean annual SAT (reanalyses minus observations) differ slightly from $0.06{ }^{\circ} \mathrm{C} / 10$ years (1951-2015) to only $0.01{ }^{\circ} \mathrm{C} / 10$ years (RRAW period). The worst results are seen for the climatic regions, where for some periods the

Table 5 Differences in seasonal and annual SAT trends $\left({ }^{\circ} \mathrm{C}\right.$ decade $\left.{ }^{-1}\right)$ between mean reanalysis and observations in the Arctic and its climatic regions

\begin{tabular}{|c|c|c|c|c|c|c|c|c|c|c|c|}
\hline Region & Period & DJF & MAM & JJA & SON & YEAR & DJF* & MAM* & JJA* & SON* & YEAR* \\
\hline \multirow[t]{4}{*}{ ATLR } & $1951-2015$ & 0.21 & 0.14 & 0.07 & 0.08 & 0.13 & 0.20 & 0.13 & 0.04 & 0.06 & 0.11 \\
\hline & 1981-2010 & -0.17 & -0.11 & -0.18 & -0.13 & -0.14 & -0.11 & 0.09 & -0.16 & -0.09 & -0.11 \\
\hline & $1976-2015$ & -0.03 & 0.01 & -0.04 & -0.02 & -0.02 & -0.05 & 0.06 & -0.10 & -0.07 & -0.06 \\
\hline & 1996-2015 & -0.10 & -0.02 & 0.17 & 0.17 & 0.06 & -0.17 & -0.09 & -0.07 & -0.06 & -0.10 \\
\hline \multirow[t]{4}{*}{ SIBR } & $1951-2015$ & 0.10 & 0.03 & 0.01 & 0.12 & 0.05 & 0.11 & 0.05 & -0.03 & 0.12 & 0.05 \\
\hline & 1981-2010 & -0.07 & 0.17 & -0.06 & -0.14 & -0.03 & -0.01 & 0.46 & -0.04 & -0.06 & 0.02 \\
\hline & $1976-2015$ & -0.15 & 0.06 & 0.05 & -0.04 & -0.01 & -0.11 & 0.22 & -0.03 & -0.03 & -0.01 \\
\hline & 1996-2015 & -0.48 & -0.37 & 0.06 & 0.00 & -0.19 & -0.27 & -0.15 & -0.21 & 0.03 & -0.16 \\
\hline \multirow[t]{4}{*}{ PACR } & 1951-2015 & -0.08 & 0.03 & 0.03 & 0.25 & 0.05 & -0.08 & 0.00 & -0.01 & 0.23 & 0.03 \\
\hline & 1981-2010 & -0.28 & -0.04 & 0.09 & 0.19 & 0.00 & -0.25 & 0.09 & 0.10 & 0.23 & 0.03 \\
\hline & $1976-2015$ & -0.33 & -0.05 & 0.14 & 0.28 & 0.02 & -0.34 & -0.09 & 0.04 & 0.25 & -0.03 \\
\hline & 1996-2015 & 0.04 & 0.17 & 0.45 & 0.48 & 0.30 & 0.03 & -0.28 & 0.08 & 0.32 & 0.11 \\
\hline \multirow[t]{4}{*}{ CANR } & $1951-2015$ & -0.05 & -0.05 & -0.06 & 0.00 & -0.04 & -0.02 & -0.03 & -0.09 & 0.00 & -0.04 \\
\hline & 1981-2010 & -0.29 & -0.17 & -0.01 & -0.25 & -0.18 & -0.15 & 0.11 & 0.01 & -0.16 & -0.09 \\
\hline & 1976-2015 & -0.30 & -0.16 & 0.06 & -0.20 & -0.15 & -0.22 & -0.10 & -0.01 & -0.17 & -0.14 \\
\hline & 1996-2015 & -0.31 & -0.11 & 0.39 & -0.05 & -0.02 & -0.06 & -0.21 & 0.11 & -0.01 & -0.04 \\
\hline \multirow[t]{4}{*}{ BAFR } & $1951-2015$ & 0.08 & 0.07 & 0.06 & 0.11 & 0.08 & 0.09 & 0.03 & 0.02 & 0.09 & 0.07 \\
\hline & 1981-2010 & -0.14 & -0.24 & -0.17 & -0.10 & -0.17 & -0.04 & 0.19 & -0.16 & -0.07 & -0.11 \\
\hline & 1976-2015 & -0.01 & -0.10 & -0.03 & -0.02 & -0.04 & 0.03 & -0.03 & -0.13 & -0.08 & -0.08 \\
\hline & 1996-2015 & -0.24 & -0.27 & 0.19 & -0.01 & -0.08 & -0.18 & -0.34 & -0.19 & -0.28 & -0.24 \\
\hline \multirow[t]{4}{*}{ HA } & $1951-2015$ & 0.05 & 0.04 & 0.02 & 0.11 & 0.06 & 0.06 & 0.04 & -0.01 & 0.10 & 0.04 \\
\hline & 1981-2010 & -0.19 & -0.08 & -0.07 & -0.09 & -0.10 & -0.11 & 0.19 & -0.05 & -0.03 & -0.05 \\
\hline & 1976-2015 & -0.17 & -0.05 & 0.03 & 0.00 & -0.04 & -0.14 & 0.01 & -0.05 & -0.02 & -0.06 \\
\hline & 1996-2015 & -0.22 & -0.12 & 0.25 & 0.12 & 0.01 & -0.13 & -0.21 & -0.05 & 0.00 & -0.09 \\
\hline
\end{tabular}

These differences were obtained by subtracting observational data from mean reanalysis values. Asterisks indicate mean reanalysis trends calculated excluding the MERRA-2 dataset 
differences in trends exceed even $\pm 0.1^{\circ} \mathrm{C} / 10$ years. The same is observed in the case of mean seasonal values. In particular, large differences occurred for the RRAW period in winter ($0.22^{\circ} \mathrm{C} / 10$ years $)$ and summer $\left(0.25^{\circ} \mathrm{C} / 10\right.$ years $)$. Also for this period, the worst results were usually obtained for seasonal SAT trend differences calculated for climatic regions (see Table 5, left part). Seasonal and annual values of trends calculated using average SAT from five reanalyses (without data from MERRA-2) usually got closer to those calculated from observations, in particular for the shortest analysed period, i.e. the RRAW (Table 5, right part). This is, of course, a result of the fact that the MERRA-2 reanalysis shows the greatest differences with other reanalyses since 2005 .

Analysis of trend differences between SAT trends calculated using mean annual data for HA taken from individual reanalysis and observations from the CGW and RRAW periods reveals that the best approach to observations is provided by the following reanalyses: JRA-55 and ERA-Interim and, in the CGW period, also CERA-20C and NCEP-CFSR (see Table S4). Generally, similar conclusions must be formulated based of SAT trends of mean annual values averaged for particular climatic regions (Table S5). MERRA-2 again shows markedly different results than other reanalyses. The trend of mean annual SAT in the $\mathrm{CGW}$ period $\left(0.31{ }^{\circ} \mathrm{C} / 10\right.$ years $)$ is about 2.0-2.5 smaller than in all other series of data, while in the RRAW period, the trend $\left(-0.08^{\circ} \mathrm{C} / 10\right.$ years $)$ is drastically different than other ones, which ranged from $0.78^{\circ} \mathrm{C} / 10$ years (20CRv2c) to $1.42{ }^{\circ} \mathrm{C} / 10$ years (CERA-20C). Lindsay et al. (2014) found that the following reanalyses are more consistent with observations: CFSR, MERRA and ERA-Interim. Two of them were also included in the group of best reanalyses in this paper. We used the newest versions of two reanalyses: MERRA-2 (instead of MERRA used by Lindsay et al. 2014) and JRA-55 (instead of JRA-25). Based on our results and the results presented by Lindsay et al. (2014), we must conclude that the quality and reliability of data available in MERRA-2 version is now worst, while the opposite must be concluded for JRA-55: Now, this new version is one of the best among the available reanalyses.

\section{Conclusions and final remarks}

The main results obtained from our investigations can be summarised as follows.

1. Detailed research into air temperature tendencies in the Arctic based on instrumental data for the periods 19512015, 1976-2015 and 1996-2015 revealed the predominance of positive trends, statistically significant at the level of 0.05 .

2. In the CGW and RRAW periods, the rate of warming was on average 2-3 times greater than that of the entire study period. This is particularly true for mean annual values for the entire Arctic, and also for seasonal means (DJF, MAM, etc.) for the period 1976-2015. This means that, in the HA, a slowdown in rate of warming (a "hiatus") in the recent two decades (noted for the $\mathrm{NH}$ ) is not present.

3. In the RRAW period, very large increases in both seasonal and annual means were observed in the ATLR and SIBR, while in the rest of the Arctic, the rate of warming was usually weaker than trends for the CGW period. In particular, there was a large fall in the rate of warming in spring, with near-zero trends (BAFR and CANR) and even a negative trend $\left(-0.34{ }^{\circ} \mathrm{C} / 10\right.$ years, PACR).

4. The scale of warming in the RRAW period relative to the reference period 1951-1990 ranges from $1.3^{\circ} \mathrm{C}$ (BAFR) to $1.7^{\circ} \mathrm{C}$ (ATLR). The average anomaly for the entire HA reached $1.6^{\circ} \mathrm{C}$. The greatest warmings were for autumn $\left(1.9^{\circ} \mathrm{C}\right)$ and winter $\left(1.7^{\circ} \mathrm{C}\right)$, while the smallest was in summer $\left(0.9^{\circ} \mathrm{C}\right)$.

5. The quality of reanalysis products significantly improved when satellite data were assimilated (i.e. since 1979). As a result, trends in SAT calculated using reanalyses data for the last 30-40 years are closer to trends from observations than they are for longer periods. For 1951-2015, reanalyses usually overestimate Arctic warming, while for the last two to four decades, they show similar or smaller warming than that calculated from observations.

6. Our results also reveal that generally two reanalysis products: the ERA-Interim and JRA-55 are the closest to the observational data for both recent periods ( $\mathrm{CGW}$ and RRAW). For the first period, a very good fit with observations is also observable for CERA-20C and NCEPCFSR. However, data averaged from all six reanalyses reveal the best fit with observations. Therefore, although all the individual reanalyses mentioned above can be used as a good substitute for the observational data, we suggest and give preference to using averaged data from reanalyses.

7. Great PA (2-4 times greater increase in SAT in HA in the period 1996-2015 in comparison to $\mathrm{NH}$, according to PA1 and PA3-PA5 metrics) was found. However, in light of the new metrics proposed in this paper (PA6 and PA7), using scaled and standardised SAT data in calculations of anomalies and trend changes, respectively, the existence of PA was generally not confirmed. We found generally a close fit between standardised series of HA and NH in the entire period 1951-2015,

8. In the study of long-term SAT trends (for periods starting before 1979 and ending in the present times) in almost the entire Arctic (except the interior Arctic region), but in particular for local- and regional-scale applications, it is still better to use good quality homogenised data series from weather stations than data from gridded climate 
datasets and reanalysis products. On the other hand, for the interior Arctic region, due to the lack of long-term observational data, based on results obtained for other parts of the Arctic, we suggest using the JRA-55 as well as averaged data from many reanalyses, and for the shorter period (since 1979) to also use the ERA-Interim (see Fig. 10).

A brief history of the development of reanalyses reveals that their quality and reliability has significantly improved in this time. The first versions of reanalyses, similar to general circulation models and regional climate models, supplied climatic information for the Arctic that was far removed from the reality described by instrumental observations. A growing number of data more reliably describing the Arctic climate system (SST, sea ice, state of the atmosphere and land surface) have been incorporated into the reanalyses, in particular after 1979 (e.g. satellite data and meteorological data from automatic stations operating in buoys and drifting stations in the central Arctic). This new data input markedly corrected mainly the SAT available in the recent versions of the reanalyses. The results presented in the paper are a good example confirming this statement. On the other hand, other meteorological variables, including different climate indices, in particular those describing extremes, are still poorly represented in the majority of available reanalysis products (for details, see Diaconescu et al. 2017). Reanalyses are also not able to correctly capture vertical temperature changes up to about $900 \mathrm{~m}$ in the Arctic (see Jakobson et al. 2012). This means that in the last 20 years, although great achievements in improving reanalysis products have been made, they still do not allow for a reliable and comprehensive description of most of the variables needed to characterise the state of the atmosphere in the Arctic. Thus, there is still a lot of work to do to improve Arctic reanalyses. Cullather et al. (2016) in sections 5 and 6 in their paper present some suggestions for future work which should be undertaken in order to improve new versions of the reanalyses for the Arctic.

Acknowledgements The ERA-Interim and CERA-20C datasets were kindly made available by the European Centre for Medium-Range Weather Forecasts. We thank the Research Data Archive of the National Center for Atmospheric Research, University Corporation for Atmospheric Research for providing the NCEP-CFSR and JRA-55 datasets. The MERRA-2 dataset was provided courtesy of the Data and Information Services Center of the National Aeronautics and Space Administration. The BEST dataset was made available by the Berkeley Earth. Thanks also go to the Climate Research Unit for providing CRUTEM4 and HadCRUT4.

Funding information The research work was supported by a grant entitled "Causes of the early 20th century Arctic warming", funded by the National Science Centre, Poland (Grant No. 2015/19/B/ST10/02933). Support for the Twentieth Century Reanalysis Project version $2 \mathrm{c}$ dataset is provided by the U.S. Department of Energy, Office of Science Biological and Environmental Research (BER) and by the National Oceanic and Atmospheric Administration Climate Program Office.

\section{Compliance with ethical standards}

Conflict of interest The authors declare that they have no conflict of interest.

Open Access This article is distributed under the terms of the Creative Commons Attribution 4.0 International License (http:// creativecommons.org/licenses/by/4.0/), which permits unrestricted use, distribution, and reproduction in any medium, provided you give appropriate credit to the original author(s) and the source, provide a link to the Creative Commons license, and indicate if changes were made.

\section{References}

ACIA (2004) Impacts of a warming Arctic: Arctic climate impact assessment. ACIA overview report. Cambridge University Press, Cambridge, $140 \mathrm{pp}$

Alexeev VA, Walsh JE, Ivanov VV, Semenov VA, Smirnov AV (2017) Warming in the Nordic seas, North Atlantic storms and thinning Arctic sea ice. Environ Res Lett 12:084011. https://doi.org/10. 1088/1748-9326/aa7a1d

Bekryaev RV, Polyakov IV, Alexeev VA (2010) Role of polar amplification in long-term surface air temperature variations and modern arctic warming. J Clim 23:3888-3906. https://doi.org/10.1175/ 2010JCLI3297.1

Brohan P, Kennedy JJ, Harris I, Tett SFB, Jones PD (2006) Uncertainty estimates in regional and global observed temperature changes: a new data set from 1850. J Geophys Res 111:D12106. https://doi. org/10.1029/2005JD006548

Bromwich DH, Fogt RL, Hodges KI, Walsh JE (2007) A tropospheric assessment of the ERA-40, NCEP, and JRA-25 global reanalyses in the polar regions. J Geophys Res 112:D10111. https://doi.org/10. 1029/2006JD007859

Chylek P, Folland CK, Lesins G, Dubey MK, Wang M (2009) Arctic air temperature change amplification and the Atlantic multidecadal oscillation. Geophys Res Lett 36:L14801. https://doi.org/10.1029/ 2009GL038777

Compo GP, Whitaker JS, Sardeshmukh PD, Matsui N, Allan RJ, Yin X, Gleason BE, Vose RS, Rutledge G, Bessemoulin P, Brönnimann S, Brunet M, Crouthamel RI, Grant AN, Groisman PY, Jones PD, Kruk M, Kruger AC, Marshall GJ, Maugeri M, Mok HY, Nordli Ø, Ross TF, Trigo RM, Wang XL, Woodruff SD, Worley SJ (2011) The twentieth century reanalysis project. Q J R Meteorol Soc 137:128. https://doi.org/10.1002/qj.776

Cowtan K, Way RG (2014) Update to 'Coverage bias in the HadCRUT4 temperature series and its impact on recent temperature trends'. Reconciling global temperature series 4: 27 pp. doi: https://doi.org/ 10.13140/RG.2.1.4334.8564

Cullather RI (2017) Understanding Arctic surface temperature differences in reanalyses, ECMWF, $5^{\text {th }}$ international conference on reanalysis (ICR5), 13-17 November 2017, Rome, p 126

Cullather RI, Hamill T, Bromwich D, Wu X, Taylor P (2016) Systematic improvements of reanalyses in the Arctic (SIRTA) White paper. Developed for the Interagency Arctic Research Policy Committee (IARPPC). http://www.iarpccollaborations.org/uploads/ cms/ documents/sirta-white-paper-final.Pdf (accessed 21 May 2016)

Cullather RI, Zhao B, Shuman Ch, Nowicki S (2017) Understanding Arctic surface temperature differences in reanalyses. Poster GC53E-0933, AGU 11-15 Dec. 2017, New Orleans, also: http:gmao.gsfc.nasa.gov 
Davy R, Chen L, Hanna E (2018) Arctic amplification metrics. Int J Climatol 38:4384 4394. https://doi.org/10.1002/joc.5675

Dee DP, Uppala SM, Simmons AJ, Berrisford P, Poli P, Kobayashi S, Andrae U, Balmaseda MA, Balsamo G, Bauer P, Bechtold P, Beljaars ACM, van de Berg L, Bidlot J, Bormann N, Delsol C, Dragani R, Fuentes M, Geer AJ, Haimberger L, Healy SB, Hersbach H, Hólm EV, Isaksen L, Kållberg P, Köhler M, Matricardi M, McNally AP, Monge-Sanz BM, Morcrette J-J, Park B-K, Peubey C, de Rosnay P, Tavolato C, Thépaut J-N, Vitart F (2011) The ERA-interim reanalysis: configuration and performance of the data assimilation system. Q J R Meteorol Soc 137:553-597. https://doi.org/10.1002/qj. 828

Dee D, Fasullo J, Shea D, Walsh J \& National Center for Atmospheric Research Staff (Eds). (Last modified 12 Dec 2016) "The climate data guide: atmospheric reanalysis: overview \& comparison tables." Retrieved from https://climatedataguide.ucar.edu/climate-data/ atmospheric-reanalysis-overview-comparison-tables

Diaconescu EP, Mailhot A, Brown R, Chaumont D (2017) Evaluation of CORDEX-Arctic daily precipitation and temperature-based climate indices over Canadian Arctic land areas. Clim Dyn 50:2061-2085. https://doi.org/10.1007/s00382-017-3736-4

Dodd EM, Merchant CJ, Rayner NA, Morice CP (2015) An investigation into the impact of using various techniques to estimate Arctic surface air temperature anomalies. J Clim 28:1743-1763. https://doi. org/10.1175/JCLI-D-14-00250.1

Dowdeswell JA, Hagen JO, Björnsson H, Glazovsky AF, Harrison WD, Holmlund P, Jania J, Koerner RM, Lefauconnier B, Ommanney CSL, Thomas RH (1997) The mass balance of circum-Arctic glaciers and recent climate change. Quat Res 48:1-14. https://doi.org/ 10.1006/qres.1997.1900

Francis JA, Vavrus SJ (2015) Evidence for a wavier jet stream in response to rapid Arctic warming. Environ Res Lett 10:014005. https://doi. org/10.1088/1748-9326/10/1/014005

Fujiwara M, Wright JS, Manney GL, Gray LJ, Anstey J, Birner T, Davis S, Gerber EP, Harvey VL, Hegglin MI, Homeyer CR, Knox JA, Krüger K, Lambert A, Long CS, Martineau P, Molod A, MongeSanz BM, Santee ML, Tegtmeier S, Chabrillat S, Tan DGH, Jackson DR, Polavarapu S, Compo GP, Dragani R, Ebisuzaki W, Harada Y, Kobayashi C, McCarty W, Onogi K, Pawson S, Simmons A, Wargan K, Jeffrey S, Whitaker JS, Zou C-Z (2017) Introduction to the SPARC Reanalysis Intercomparison Project (S-RIP) and overview of the reanalysis systems. Atmos Chem Phys 17:1417-1452. https://doi.org/10.5194/acp-17-1417-2017

Fyfe JC, Meehl GA, England MH, Mann ME, Santer BD, Flato GM, Hawkins E, Gillett NP, Xie S-P, Kosaka Y, Swart NC (2016) Making sense of the early-2000s warming slowdown. Nat Clim Chang 6(3):224-228

Gelaro R, McCarty W, Suárez MJ, Todling R, Molod A, Takacs L, Randles CA, Darmenov A, Bosilovich MG, Reichle R, Wargan K, Coy L, Cullather R, Draper C, Akella S, Buchard V, Conaty A, da Silva AM, Gu W, Kim G, Koster R, Lucchesi R, Merkova D, Nielsen JE, Partyka G, Pawson S, Putman W, Rienecker M, Schubert SD, Sienkiewicz M, Zhao B (2017) The modern-era retrospective analysis for research and applications, version 2 (MERRA-2). J Clim 30:54195454. https://doi.org/10.1175/JCLI-D-16-0758.1

Graham RM, Cohen L, Petty AA, Boisvert LN, Rinke A, Hudson SR, Nicolaus M, Granskog MA (2017) Increasing frequency and duration of Arctic winter warming events. Geophys Res Lett 44:6974 6983. https://doi.org/10.1002/2017GL073395

Hansen J, Ruedy R, Sato M, Lo K (2010) Global surface temperature change. Rev Geophys 48(4):RG4004. https://doi.org/10.1029/ 2010RG000345

Harig C, Simons FJ (2012) Mapping Greenland's mass loss in space and time. PNAS 109(49):19934-19937. https://doi.org/10.1073/pnas. 1206785109
IPCC (2013) Climate change 2013: the physical science basis. In: Stocker TF, Qin D, Plattner G-K, Tignor M, Allen SK, Boschung J, Nauels A, Xia Y, Bex V, Midgley PM (eds) Contribution of working group I to the fifth assessment report of the intergovernmental panel on climate change. Cambridge University Press, Cambridge $1535 \mathrm{pp}$

Jakobson E, Vihma T, Palo T, Jakobson L, Keernik H, Jaagus J (2012) Validation of atmospheric reanalyses over the central Arctic Ocean. Geophys Res Lett 39:L10802. https://doi.org/10.1029/ 2012GL051591

Jones PD, Lister DH, Osborn TJ, Harpham C, Salmon M, Morice CP (2012) Hemispheric and large-scale land surface air temperature variations: an extensive revision and an update to 2010. J Geophys Res 117:D05127. https://doi.org/10.1029/2011JD017139

Jung O, Sung M-K, Sato K, Lim Y-K, Kim S-J, Baek E-H, Jeong J-H, Kim B-M (2017) How does the SST variability over the western North Atlantic Ocean control Arctic warming over the Barents-Kara seas? Environ Res Lett 12:034021. https://doi.org/10.1088/17489326/aa5f3b

Kalnay E, Kanamitsu M, Kistler R, Collins W, Deaven D, Gandin L, Iredell M, Saha S, White G, Woollen J, Zhu Y, Chelliah M, Ebisuzaki W, Higgins W, Janowiak J, Mo KC, Ropelewski C, Wang J, Leetmaa A, Reynolds R, Jenne R, Joseph D (1996) The NCEP/NCAR 40-year reanalysis project. Bull Amer Meteor Soc 77: 437-472. https://doi.org/10.1175/1520-0477(1996)077<0437: TNYRP $>2.0 . \mathrm{CO} ; 2$

Karl TR, Arguez A, Huang B, Lawrimore JH, McMahon JR, Menne MJ, Peterson TC, Vose RS, Zhang H-M (2015) Possible artifacts of data biases in the recent global surface warming hiatus. Science 348(6242):1469-1472. https://doi.org/10.1126/science.aaa5632

Kennedy JJ, Rayner NA, Smith RO, Saunby M, Parker DE (2011) Reassessing biases and other uncertainties in sea-surface temperature observations since 1850 part 1: measurement and sampling errors. J Geophys Res 116:D14103. https://doi.org/10.1029/ 2010JD015218

Kistler R, Kalnay E, Collins W, Saha S, White G, Woollen J, Chelliah M, Ebisuzaki W, Kanamitsu M, Kousky V, van den Dool H, Jenne R, Fiorino M (2001) The NCEP-NCAR 50-year reanalysis: monthly means CD-ROM and documentation. Bull Amer Meteor Soc 82: 247-268. https://doi.org/10.1175/1520-0477(2001)082<0247: TNNYRM>2.3.CO;2

Klaus D, Wyszyński P, Dethloff K, Przybylak R, Rinke A (2018) Evaluation of 20CR reanalysis data and model results based on historical (1930-1940) observations from Franz Josef Land. Polish Polar Research 36(2):225-254. https://doi.org/10.24425/118747

Kobashi T, Shindell DT, Kodera K, Box JE, Nakaegawa T, Kawamura K (2013) On the origin of multidecadal to centennial Greenland temperature anomalies over the past 800 years. Clim Past 9:583-596. https://doi.org/10.5194/cp-9-583-2013

Kobayashi S, Ota Y, Harada Y, Ebita A, Moriya M, Onoda H, Onogi K, Kamahori H, Kobayashi C, Endo H, Miyaoka K, Takahashi K (2015) The JRA-55 reanalysis: general specifications and basic characteristics. J Met Soc Jap 93(1):5-48. https://doi.org/10.2151/ jmsj.2015-001

Kohnemann SHE, Heinemann G, Bromwich D, Gutjahr O (2017) Extreme warming in the Kara Sea and Barents Sea during the winter period 2000-16. J Clim 30:8913-8927. https://doi.org/10.1175/ JCLI-D-16-0693.1

Laloyaux P, de Boisséson E, Dahlgren P (2016) CERA-20C: an Earth system approach to climate reanalysis. ECMWF Newsletter 150: 25-30. https://doi.org/10.21957/ffs36birj2

Lindsay R, Wensnahan M, Schweiger A, Zhang J (2014) Evaluation of seven different atmospheric reanalysis products in the Arctic. J Clim 27:2588-2606. https://doi.org/10.1175/JCLI-D-13-00014.1

Liu J, Zhang Z, Hu Y, Chen L, Dai Y, Ren X (2008) Assessment of surface air temperature over the Arctic Ocean in reanalysis and 
IPCC AR4 model simulations with IABP/POLES observations. J Geophys Res 113:D10105. https://doi.org/10.1029/2007JD009380

Martin S, Munoz E, Drucker R (1997) Recent observations of a springsummer surface warming over the Arctic Ocean. Geophys Res Lett 24:1259-1262. https://doi.org/10.1029/97GL01126

McCarty W, Coy L, Gelaro R, Huang A, Merkova D, Smith EB, Sienkiewicz M, Wargan K (2016) MERRA-2 input observations: summary and assessment. In: Koster RD (ed) Technical report series on global modeling and data assimilation, volume 46. National Aeronautics and Space Administration Goddard Space Flight Center NASA/TM-2016-104606/Vol. 46, $51 \mathrm{p}$

Morice CP, Kennedy JJ, Rayner NA, Jones PD (2012) Quantifying uncertainties in global and regional temperature change using an ensemble of observational estimates: the HadCRUT4 dataset. J Geophys Res 117:D08101. https://doi.org/10.1029/2011JD017187

Overland JE, Dethloff K, Francis JA, Hall RJ, Hanna E, Kim S-J, Screen JA, Shepherd TG, Vihma T (2016) Nonlinear response of midlatitude weather to the changing Arctic. Nat Clim Chang 6:992999. https://doi.org/10.1038/NCLIMATE3121

Perovich D, Richter-Menge J, Jones KF, Light B (2008) Sunlight, water, and ice: extreme Arctic sea ice melt during the summer of 2007. Geophys Res Lett 35:L11501. https://doi.org/10.1029/2008GL034007

Polyakov IV, Bekryaev RV, Alekseev GV, Bhatt US, Colony RL, Johnson MA, Maskshtas AP, Walsh D (2003) Variability and trends of air temperature and pressure in the maritime Arctic, 1875-2000. J Clim 16:2067-2077. https://doi.org/10.1175/15200442(2003)016<2067: VATOAT $>2.0 . \mathrm{CO} ; 2$

Przybylak R (1996) Zmienność temperatury powietrza i opadów atmosferycznych w okresie obserwacji instrumentalnych w Arktyce (variability of air temperature and recipitation over the period of instrumental observations in the Arctic), Wydawnictwo Uniwersytetu M. Kopernika, Toruń, 280 pp.

Przybylak R (2000) Temporal and spatial variation of air temperature over the period of instrumental observations in the Arctic. Int $\mathrm{J}$ Climatol 20:587-614. https://doi.org/10.1002/(SICI)10970088(200005)20:6<587::AID-JOC480>3.0.CO;2-H

Przybylak R (2002) Variability of air temperature and atmospheric precipitation in the Arctic. Atmospheric and Oceanographic Sciences Library, 25. Kluwer Academic, Dordrecht, p 330

Przybylak R (2007) Recent air-temperature changes in the Arctic. Annals Glaciology 46:316-324. https://doi.org/10.3189/ 172756407782871666

Przybylak R (2016) The climate of the Arctic, Second edition, Springer, 287 pp. doi: https://doi.org/10.1007/978-3-319-21696-6

Przybylak R, Wyszyński P, Vízi Z, Jankowska J (2013) Atmospheric pressure changes in the Arctic from 1801 to 1920. Int J Climatol 33:1730-1760. https://doi.org/10.1002/joc.3546

Przybylak R, Wyszyński P, Nordli Ø, Strzyżewski T (2016) Air temperature changes in Svalbard and the surrounding seas from 1865 to 1920. Int J Climatol 36:2899-2916. https://doi.org/10.1002/joc4527

Rapaić M, Brown R, Markovic M, Chaumont D (2015) An evaluation of temperature and precipitation surface-based and reanalysis datasets for the Canadian Arctic, 1950-2010. Atmosphere-Ocean 53(3): 283-303. https://doi.org/10.1080/07055900.2015.1045825

Rigor IG, Colony RL, Martin S (2000) Variations in surface air temperature observations in the Arctic, 1979-1997. J Clim 13:896-914. https://doi.org/10.1175/1520-0442(2000)013<0896:VISATO>2.0. $\mathrm{CO} ; 2$

Rodionov SN (2004) A sequential algorithm for testing climate regime shifts. Geophys Res Lett 31:L09204. https://doi.org/10.1029/ 2004GL019448

Rodionov SN (2006) Use of prewhitening in climate regime shift detection. Geophys Res Lett 33:L12707. https://doi.org/10.1029/ 2006GL025904

Rohde R, Muller RA, Jacobsen R, Muller E, Perimutter S, Rosenfeld A, Wurtele J, Groom D, Wickham C (2013) A new estimate of the average earth surface land temperature spanning 1753 to 2011 . Geoinform Geostat 1:1-7. https://doi.org/10.4172/2327-4581. 1000101

Saha S, Moorthi S, Pan H, Wu X, Wang J, Nadiga S, Tripp P, Kistler R, Woollen J, Behringer D, Liu H, Stokes D, Grumbine R, Gayno G, Wang J, Hou Y, Chuang H, Juang HH, Sela J, Iredell M, Treadon R, Kleist D, Van Delst P, Keyser D, Derber J, Ek M, Meng J, Wei H, Yang R, Lord S, van den Dool H, Kumar A, Wang W, Long C, Chelliah M, Xue Y, Huang B, Schemm J, Ebisuzaki W, Lin R, Xie P, Chen M, Zhou S, Higgins W, Zou C, Liu Q, Chen Y, Han Y, Cucurull L, Reynolds RW, Rutledge G, Goldberg M (2010) The NCEP climate forecast system reanalysis. Bull Amer Meteor Soc 91:1015-1058. https://doi.org/10.1175/2010BAMS3001.1

Serreze MC, Barry RG (2014) The Arctic climate system, 2nd edn. Cambridge University Press, Cambridge, $415 \mathrm{pp}$

Serreze MC, Francis JA (2006) The Arctic amplification debate. Clim Chang 76:241-264. https://doi.org/10.1007/s10584-005-9017-y

Simmons AJ, Poli P (2015) Arctic warming in ERA-interim and other analyses. Q J R Meteorol Soc 141:1147-1162. https://doi.org/10. $1002 /$ qj. 2422

Simmons AJ, Berrisford P, Dee DP, Hersbach H, Hirahara S, Thépaut J (2017) A reassessment of temperature variations and trends from global reanalyses and monthly surface climatological datasets. Q J R Meteorol Soc 143:101-119. https://doi.org/10.1002/qj.2949

Smith TM, Reynolds RW, Peterson TC, Lawrimore J (2008) Improvements to NOAA's historical merged land-ocean surface temperature analysis (1880-2006). J Clim 21:2283-2296. https:// doi.org/10.1175/2007JCLI2100.1

Treshnikov AF (ed) (1985) Atlas Arktiki. Glavnoye Upravlenye Geodeziy i Kartografiy, Moscow

Vízi Z, Przybylak R (2006) Reanaliza NCEP/NCAR i możliwości jej wykorzystania do badań rozkładu przestrzennego temperatury powietrza w Arktyce i Subarktyce Amerykańskiej (NCEP/NCAR reanalysis and its usefulness in the study of the spatial distribution of air temperature in the American Arctic and Subarctic). Annales Universitatis Mariae Curie-Skłodowska, Sectio B: Geographia, Geologia, Mineralogia et Petrographia LXI: 436-445

Walczowski W, Piechura J, Goszczko I, Wieczorek P (2012) Changes in Atlantic water properties: an important factor in the European Arctic marine climate. ICES J Mar Sci 69:864-869. https://doi.org/10. 1093/icesjms/fss068

Way RG, Bonnaventure PP (2015) Testing a reanalysis-based infilling method for areas with sparse discontinuous air temperature data in northeastern Canada. Atmos Sci Let 16:398-407. https://doi.org/10. 1002/asl2.574

Way RG, Lewkowicz AG, Bonnaventure PP (2017) Development of moderate-resolution gridded monthly air temperature and degreeday maps for the Labrador-Ungava region of northern Canada. Int J Climatol 37(1):493-508

Wegmann M, Brönnimann S, Compo GP (2017) Tropospheric circulation during the early twentieth century Arctic warming. Clim Dyn 48: 2405-2418. https://doi.org/10.1007/s00382-016-3212-6

Wilks DS (2011) Statistical methods in the atmospheric sciences. $3^{\text {rd }}$ edition. International geophysics series. 100. Academic Press is an imprint of Elsevier, Oxford, $704 \mathrm{p}$

Yurova A, Bobylev LP, Zhu Y, Davy R, Korzhikov AY (2019) Atmospheric heat advection in the Kara Sea region under main synoptic processes. Int J Climatol 39(1):361-374

Zhou C, He Y, Wang K (2018) On the suitability of current atmospheric reanalyses for regional warming studies over China. Atmos Chem Phys 18:8113-8136. https://doi.org/10.5194/acp-2017-966

Publisher's note Springer Nature remains neutral with regard to jurisdictional claims in published maps and institutional affiliations. 